

\section{Sumário}

Dossiê

EDITORIAL: INTERNATIONAL LAW AND DE-GLOBALIZATION 16 Ivette Esis, Jaime Tijmes e Juan Enrique Serrano

El régimen jurídico de la Inversión Extranjera Directa: ¿De la limitación a la desGLOBALIZACIÓN?

Ivette Esis Villarroel e Yoselyn Bermúdez Abreu

Desglobalização, Brexit e os novos acordos entre Reino Unido e União Europeia .34 Angela Limongi Alvarenga Alves e Daniel Freire e Almeida

FisCALIDAD Y DESGLOBALIZACIÓN EN UN MUNDO CRECIENTEMENTE UNILATERAL Julio César Muñiz Pérez

Covid, Covax e o Refluxo da Governança Global Salem Hikmat Nasser e Luiza Nogueira Papy

The International Monetary Fund and COVID-19: Old and New Challenges of a Post-World War II INTERNATIONAL INSTITUTION

Virdzhiniya Petrova Georgieva

Artigos Sobre outros temas

RULE OF LAW IN THE INTERNATIONAL ARENA: THE IMPORTANCE OF PRACTICES OF LEGALITY . 112 Angela Jank Calixto

THE WITHDRAWAL OF MEMBER-STATES FROM HUMAN RIGHTS COURTS: IS THE JUDICIALIZATION OF MEGA-POLITICS A NECESSARY CONDITION?. 132

Mikelli Marzzini Lucas Alves Ribeiro e Ernani Rodrigues de Carvalho Neto 
Princípio da precaução e mudança climática: uma análise do Acordo de Paris e das Conferências das Partes.

Jamille Bergamaschine Mata Diz e Carolina Mendonça de Siqueira

A INTERAÇÃo ENTRE OS ESPAÇOS CONSTITUCIONAIS NACIONAIS E INTERNACIONAIS E SEUS IMPACTOS NO SISTEMA DE FONTES DO DIREITO: AS LIÇÕES DA PROTEÇÃO COOPERATIVA DE DIREITOS HUMANOS E O CASO DA INTEGRAÇÃO EUROPEIA ...................................................... 173

Diego Fernandes Guimarães

WTO’s Engagement with National Law: Three Illustrations from India 193 Ravindra Pratap

GESTÃo MIGRATÓRIA E INTEGRAÇÃo REGIONAL: UMA ANÁLISE SOBRE A REGULAMENTAÇÃo NORmativa dos fluxos migratórios irregulares na União Europeia À luz do Novo Pacto Europeu sobre Migração e Asilo.................................................................. 212 João Mauricio Malta Cavalcante Filho e Eugênia Cristina Nilsen Ribeiro Barza

The African Regional Human and Peoples' Rights System: 40 years of progress and CHALLENGES. 232 Juan Bautista Cartes Rodríguez

The USMCA Sunset Clause 258 Jaime Tijmes-Ihl e Yvonne Georgina Tovar Silva

REFLEXÕES SOBRE A UNIVERSALIDADE DO DIREITO INTERNACIONAL DOS DIREITOS HUMANOS A RESPEITO DA PROTEÇÃO ÀS MULHERES 273 Érica Rios de Carvalho

A CRItical legal anAlysis OF GENDER EQUALITY IN INTERNATIONAL TRADE AgREEMENTS...287 Parul Shukla e Sheikh Sultan Aadil Huque

FEMinicídio, FEMicídio E Ódio NA AGENDA: o ASSASSinAto DAS MUlHERES NA AmÉriCA LATINA...... 309 Vinícius Ferreira Baptista

LEGAL IDEOLOGY IN THE CONTEXT OF DEVELOPMENT OF THE LEGAL STATE AND FORMATION OF THE CIVIL SOCIETY IN UKRAINE 
Direito INTERNACIONAL PÚBLICO NO ENTREgUERRAS (1919-39): A INSTITUCIONALIZAÇÃO DOS PROJETOS JURÍDICOS DE PAZ E MANEJO DOS POVOS NÃO SOBERANOS.

Hugo Luís Pena Ferreira

O Caso Gomes Lund (“Guerrilha Do Araguaia”) dez anos depois: Desafios para o cumPRIMENTO INTEGRAL PELO ESTADO BRASILEIRO

João Gabriel Archegas, Felipe Klein Gussoli e Vivian Cristina Lima López Valle

DiÁlogos museológicos: o Regime jurídico brasileiro e o Código de Ética do ConseLHo InTERnacional de Museus.

Paula Gonçalves do Carmo, Emerson Gabardo e Daniel Wunder Hachem 


\title{
The African Regional Human and Peoples' Rights System: 40 years of progress and challenges*
}

\author{
O Sistema Regional Africano de Direitos \\ Humanos e dos Povos: 40 anos de progresso e \\ desafios
}

Juan Bautista Cartes Rodríguez ${ }^{* *}$

\begin{abstract}
The purpose of this paper is to provide a comprehensive and detailed analysis of the African regional human rights system, emphasizing both its innovations and remaining challenges. To this end, a literature review of primary sources, as well as the jurisprudence of the human rights bodies of the African system, will be analyzed. Although this system did not start functioning until the decade of the eighties of the 20th century, it has evolved considerably once the African Charter on Human and Peoples' Rights was adopted. Thus, several other treaties followed it, of which the African Charter on the Rights and Welfare of the Child and the Protocol to the African Charter on Human and Peoples Rights on the Rights of Women in Africa can be pointed out. And even though initially only the creation of protection and control mechanisms was foreseen -the African Commission on Human and People's Rights and the African Committee of Experts on the Rights and Welfare of the Child- after 1998, the African Court on Human and Peoples' Rights was added, which has progressively adopted a protectionist and growing jurisprudence; but also that, as its predecessors, will face different challenges, among which the reform process of the judicial bodies of the African Union themselves. In any case, the main conclusion of this article is that the innovations of the system are considerable (and largely unknown), although outstanding challenges need to be addressed to ensure the effectiveness and development of the system.
\end{abstract}

Keywords: Africa; Human rights; African regional system; Judicial bodies; Quasi-judicial bodies.

* Recebido em 23/08/2021

Aprovado em 21/12/2021

** International Law Predoctoral Researcher and Professor at Complutense University of Madrid. Junior Research Fellow at the EuroMediterranean University Institute (EMUi). Adjunct Coordinator of the Amnesty International Spain Middle East Team.

Email: jcartes@ucm.es

\section{Resumo}

Objetivo do artigo: O objetivo deste artigo é examinar os aspectos teóricos e práticos da prisão e transferência por um estado para outro (a pedido) de uma pessoa suspeita ou acusada de cometer um crime ou um infrator condenado. Metodologia: Os autores utilizam métodos de pesquisa como análise de sistemas, direito comparado, métodos documentais, bibliográficos, dialéticos, dogmáticos, lógico-legais, sistêmico-estruturais e de modelagem. 
Conclusões: Após a realização deste estudo, os autores sugeriram suas próprias formas de resolver aspectos problemáticos da regulamentação legal da extradição na Ucrânia. Originalidade ou valor: Este estudo analisa a legislação ucraniana e as decisões do Tribunal Europeu dos Direitos Humanos. O estudo da detenção fora do território da Ucrânia do ponto de vista da legislação nacional da Ucrânia e do Tribunal Europeu de Direitos Humanos é complementar. Este artigo define os fundamentos legais e o procedimento para a extradição de pessoas que cometeram um crime fora do território da Ucrânia. São analisadas as peculiaridades da legislação nacional em caso de detenção de uma pessoa que cometeu um crime fora do território da Ucrânia, são identificadas questões problemáticas nesta área e são propostas soluções próprias. $\mathrm{O}$ aspecto da realização dos direitos e liberdades do detento, incluindo o direito à proteção, é investigado separadamente.

Palavras-chave: extradição de criminosos; extradição; detenção; prisão temporária; prisão de extradição.

\section{Introductory Issues}

In 1961, within the framework of the African Conference on the Rule of Law organized by the International Commission of Jurists, a declaration was adopted- which later came to be known as the "Law of Lagos" under which the governments of recently independent African States were encouraged to adopt a human rights convention for the continent, guided by the spirit of the Universal Declaration of Human Rights; with a Court as its protection and monitoring mechanism ${ }^{1}$.

Only two years after the abovementioned Conference, on May 256h 1963, 32 African States agreed on the founding document of a new international organization, the Organization for African Unity (henceforth, OAU) ${ }^{2}$.

\footnotetext{
${ }^{1}$ See INTERNATIONAL COMMISSION OF JURISTS. Report on the proceedings of the African Conference on the Rule of Law. Lagos (Nigeria), p. 11, January 3-7, 1961.

2 For a study on the role of the above-mentioned Organization on the continent, as well as its origin and evolution, see ELIAS, T. O. "The Charter of the Organization of African Unity". The American Journal of International Law, v. 59, n. 2, p. 243-267, 1965; PADELFORD, N. J. "The Organization of African Unity". International Organization, v. 18, n. 3, p. 521-542, 1964; WALRAVEN, V. K. Dreams of power: The role of the Organization of African Unity in the politics of Africa: 1963-1993. London: Routledge, 1999; specifically in what concerns human rights, WELCH, C. E. "The Organisation of
}

Nevertheless, among its principles and objectives, the non-intervention in the internal affairs of States and the respect for recently acquired sovereignty prevailed; the promotion and protection of human rights within the state system was among them, and it was destined only for international relations ${ }^{3}$.

Thereby, the OAU Charter was built on an instrument which condemned colonialism and interventions and human rights violations by third States, but, contradictorily, these violations were not forbidden if they were committed by new African leaders on regarding their own population.

Thus, atrocious regimes occurred, such as those of Kenyan Ara Moi, Zairean Mobutu Sese Seko, Central African Jean-Bedel Bokassa, as well as of Guinean Macías Nguema or Ugandan Idi Amin; the latter even ended up presiding the OAU itself ${ }^{4}$. Nonetheless, pressure by the international community and by different UN bodies and agencies, the end of three last three abovementioned dictatorial regimes in 1979, along with growing voices from the continent, led the role of the protection and promotion of human rights in Africa to stand out more and more.

As in 1981 the African Charter on Human and Peoples' Rights was adopted under the auspices of the $\mathrm{OAU}$, which was the cornerstone treaty for the African regional system for human rights, but unlike its predecessors- the European or American system - it only had one Commission as a protection and monitoring mechanism at the outset, and not a judicial body ${ }^{5}$.

Once again, a new tragedy had to occur, the terrible Rwandan genocide, for African Heads of State and Government - under the influence of the of turn of

African Unity and the promotion of human rights". The Journal of Modern African Studies, v. 29, n. 4, p. 535-555, 1991.

3 See article 2.1.e) and para. 9 of the Preamble of the OAU Charter. Albeit the OAU did dedicate specific work to two subjects of the continent connected to human rights: the fight against apartheid and the exercise of the right to self-determination of peoples submitted to colonial domination. On this subject, see, LANGELY, W. E.; OKOLO, J. E.; LANGLEY, W. E. "The Organization of African Unity and Apartheid: constraints on resolution". World Affairs, v. 137, n. 3, p. 206-232, 1974; DUGARD, C. J. "The Organisation of African Unity and Colonialism: an Inquiry into the Plea of SelfDefence as a Justification for the use of Force in the Eradication of Colonialism". International and Comparative Law Quarterly, v. 16, n. 1, p. 157-190, 1967.

${ }_{4}^{4}$ During the years of 1975 and 1976.

5 At the core of the OAU, a special reference should be made to the role of Léopold Senghor, President of Senegal at the time. 
the millennium and with the ending of decolonization - to decide to renew the objectives and to highlight the weaknesses of the OAU, and it was substituted by a new international organization: the African Union. It was created by the Constitutive Act of the 11 th of July 2000 , and that, unlike its predecessor, included the promotion and protection of human rights on the continent among its principles and objectives, as well as the respect for democratic principles and for the Rule of Law. $^{6}$

It is in this new phase that the African regional system becomes more robust; in such a way that, along with the African Charter of the Child, adopted in 1990 and which entered into force in 1999, the African Charter on Human and Peoples' Rights is complemented by two additional Protocols, one with the purpose of the creation of a judicial body in charge of its supervision (adopted in 1998 and in force since 2004), and a second protocol dedicated to women's rights (from 2003, in force since 2005).

In view of the above and taking into consideration that the purpose of this paper is to offer an exhaustive and detailed analysis of the African regional human rights system, emphasizing both its innovations and the challenges that still persist, we have conducted this paper through a bibliographical review of primary sources, as well as the jurisprudence of the human rights bodies of the African system.

With this in mind, we will start by analysing the main treaties of the system (2), namely, the African Charter on Human and Peoples' Rights (2.1); the African Charter on the Rights and Welfare of the Child (2.2); and the Protocol to the African Charter on Human and Peoples' Rights on the Rights of Women in Africa (2.3). They will be a prelude for an analysis focused on their protection and control mechanisms as a follow up (3); taking into account their quasi-judicial mechanisms

\footnotetext{
${ }^{6}$ See articles 3. f, g and h; 4. $\mathrm{m}$ and p. Regarding the bibliography of the African Union, see BADEJO, D. L. The African Union. New York: Chelsea Hause Publishers, 2008; PACKER, C. A.; RUKARE, D. "The new African Union and its constitutive act". American Journal of International Law, p. 365-379, 2002; MALUWA, T. "The constitutive act of the African Union and institution-building in postcolonial Africa". Leiden Journal of International Law, v. 16, n. 1, p. 157-170, 2003; NMEHIELLE, V. O. "The African Union and African Renaissance: A New Era for Human Rights Protection in Africa?". Singapore Journal of International \& Comparative Law, v. 7, p. 412-446, 2003; MURRAY, R. Human rights in Africa: from the OAU to the African Union. Cambridge: Cambridge University Press, 2004.
}

(3.1) -the African Commission on Human and Peoples' Rights (3.1.1) the African Committee of Experts on the Rights and Welfare of the Child (3.1.2)-, as well as their judicial mechanisms (3.2). Albeit, on this last point, taking into account that the only regional court which is operating at the moment is the African Court on Human and Peoples' Rights (3.2.1); on the other hand, two other additional courts - The African Court of Justice and Human Rights and the African Court of Justice and Human and Peoples' Rights (3.2.2)- are waiting for their respective constitutive Protocols to enter into force on one hand; and that, on the other, alongside the abovementioned regional courts, certain subregional courts which deal with human rights issues (3.2.3). Lastly, we will finish with a series of conclusions on the matters which are approached in this analysis (4).

\section{Main treaties of the system}

\subsection{The African Charter on Human and Peoples' Rights.}

As we have already pointed out, the African Charter on Human and Peoples' Rights (henceforth "Charter" or "African Charter") is based on the axis treaty of the African regional system ${ }^{8}$. Adopted on the 1 st of June 1981, it came into force in October of 1986, when a simple majority of Member States which then were a part of the Organization for African Unity presented its respective ratification and accession instruments (art. 63.3). Currently, of the 55 Member States which compose the AU, only Morocco is not Party to it?

\footnotetext{
Also called the Banjul Charter as it is the Gambian capital where its adoption occurred.

8 The printed version of the African Charter is available in HEYNS, C. Human Rights Law in Africa. Leiden: Martinus Nijhoff Pubishers, 2004. p. 111-115. Several authors analysed the African Charter, among whom, UMOZURIKE, U. O. "The African Charter on Human and Peoples' Rights", The American Journal of International Law, v. 77, n. 4, p. 902-912, 1983; GITTLEMAN, R. "The African Charter on Human and Peoples' Rights: A Legal Analysis". Virginia Journal of International Law, v. 22, p. 667-714, 1981; BERMEJO GARCÍA, R. "Los derechos humanos en Africa". Anuario Español de Derecho Internacional, v. 28, p. 18-37; See HEYNS, C. "La Carta Africana de Derechos humanos y de los Pueblos" In: GÓMEZ ISA, F. (ed.). La protección internacional de los derechos humanos en los albores del siglo XXI. Bilbao: Universidad de Deusto, 2003. p. 595-620.

9 This State re-entered in 2017 after founding the Organization of African Unity and decided to abandon it due to the fact the Sahrawi
} 
As for its structure, the African Charter is divided in three parts; a first part (articles 1-29) which includes a set of individual and peoples' rights (articles 21-26) and duties (articles 27-29); a second part with the regulation of protection and monitoring mechanisms (articles 30-63); a third part on a series of technical provisions (articles 64-68).

Because of the Africanist conception which inspired the entire Charter drafting process, it includes a series of briefly highlighted specificities that will also be used as a model for other regional and universal treaties; these specificities are already noted in its Preamble as well ${ }^{10}$. Therefore, while putting forward a holistic vision of human rights, the Charter becomes the first human rights treaty which gathers a detailed list of civil and political and economic, social and cultural rights in one single document ${ }^{11}$. In the same way, it is the first time that a series of peoples' rights are also recognized ${ }^{12}$ as well

Arab Democratic Republic was admitted to the organization. In its turn, South Sudan was the last State to ratify the Charter in May of 2016. Information available at: https://au.int/treaties/ratifiedby/14 (Consulted on 15.96.2021).

10 Thus, in the same way, among other aspects, it states that "taking into consideration the virtues of their historical tradition and the values of African civilization which should inspire and characterize their reflection on the concept of human and peoples' rights $[\ldots]$ convinced that it is henceforth essential to pay particular attention to the right to development and that civil and political rights cannot be dissociated from economic, social and cultural rights in their conception as well as universality and that the satisfaction of economic, social and cultural rights is a guarantee for the enjoyment of civil and political rights; [...] firmly convinced of their duty to promote and protect human and peoples' rights and freedoms and taking into account the importance traditionally attached to these rights and freedoms in Africa". See paras. 5, 8 and 11 of the Preamble of the African Charter.

11 See articles 1 to 18 of the African Charter. Moreover, not only with its incorporation, but also its intended equalisation, since economic, social, and cultural rights are not subjected to progressive realisation clauses. Nevertheless, even though the African Court has not yet had a chance to deliver a decision on this subject, the Commission has understood that these rights are subjected to the abovementioned clauses in their implementation. See para. 3.1.1. Among the bibliography published on this subject, see AGBAKWA, S. C. "Reclaiming humanity: economic, social, and cultural rights as the cornerstone of African human rights". Yale Human Rights and Development Law Journal, v. 5, p. 177-216, 2002; CHIRWA, D. M., "Toward Revitalizing Economic, Social, and Cultural Rights in Africa". Human Rights Brief, v. 10, n. 1, p. 14-25, 2002; FONTANIVE LEAL, A. A.; MASSAÚ, G., "Justiciabilidade Direta Dos Direitos Econômicos, Sociais, Culturais E Ambientais Na Corte Interamericana De Direitos Humanos". Revista de Direito Internacional, v. 18, n. 1, p. 334-351, 2021.

${ }^{12}$ See articles 19 to 24 of the African Charter. Among the bibliography published on this subject, see KIWANUKA, R. N. "The meaning of "people" in the African Charter on Human and Peo- as, also for the first time, the right to development and certain environmental rights are mentioned in a legally binding instrument ${ }^{13}$.

Nevertheless, besides these innovations, one can find certain defects or omissions in the Charter. Possibly the most evident of which is the existence in the enunciation of certain provisions - particularly those related to the recognition of civil and political rights of certain limitation clauses, called "claw-back" clauses, which seem to recognize the rights at stake but only to the point to which does not collide with internal Law ${ }^{14}$. Similarly, in the category of civil and political rights, we point out the omission of certain rights, such as the prohibition of forced labour or the right to respect family and private life; as well as the scarce regulation of certain provisions in comparison to other human rights treaties, among which, the right to a fair trial and the rights to expression, association, and reunion ${ }^{15}$.

Another of the most highlighted criticisms of the Charter is related to the regulation of women and

ples' Rights". American Journal of International Law, v. 82, n. 1, p. 80101, 1988; BOJOSI, K. N.; WACHIRA, G. M. "Protecting indigenous peoples in Africa: An analysis of the approach of the African Commission on Human and Peoples' Rights". African Human Rights Law Journal, v. 6, n. 2, p. 382-406, 2006; NETO DIAS FRANCO, L.; FERNANDEZ DE BASTOS, D. "O processo e o direito coletivo no sistema interamericano de direitos humanos: uma análise com base na jurisprudência internacional". Revista de Direito Internacional, v. 10, n. 2, p. 250-261, 2013.

13 See, respectively, articles 22.2 to 24 of the African Charter. Among the bibliography published on this subject, see SAMPAIO LEITE, J. A.; SOUZA COSTA, B. "As complicadas inter-relações entre os sistemas internos e internacionais de proteção do direito ao meio ambiente sadio", Revista de Direito Internacional, v. 12, n. 2, p. 785-803, 2015; RESENDE, A. "A Proteção do Meio Ambiente no Sistema Interamericano de Direitos Humanos a partir do direito à Educação". Revista de Direito Internacional, v. 10, n. 2, p. 297-314, 2013. For a more detailed analysis of each one of the material provisions of the African Charter, See MURRAY, R. The African Charter on Human and Peoples' Rights: A Commentary. Oxford: Oxford University Press, 2019.

${ }^{14}$ We can find examples of this in articles 6: "every individual shall have the right to liberty and to the security of his person. No one may be deprived of his freedom except for reasons and conditions previously laid down by law"; 9.2: "every individual shall have the right to express and disseminate his opinions within the law"; or 10.1 of the Charter: "every individual shall have the right to free association provided that he abides by the law" (my highlight). For a more detailed analysis in this regard, see NALDI, G. J. "Limitation of Rights Under the African Charter on Human and Peoples' Rights: The Contribution of the African Commission on Human and Peoples' Rights". South African Journal on Human Rights, v. 17, n. 1, p. 109-118, 2001.

${ }^{15}$ In this regard, See HEYNS, C. "The African Regional Human Rights System: The African Charter". Penn State Law Review, v. 108, n. 3 , p. $687,2004$. 
children's rights, due to the fact they are only approached in a section of one provision- number 18.3- which, in its turn, is about the protection of the family ${ }^{16}$; this has led several authors to sustain this is to such a point that it maintains gender roles and that it does not incorporate an adequate recognition of their rights ${ }^{17}$.

Lastly, among the peculiarities of the Charter, we have the fact that it does not contain a general exemption clause ${ }^{18}$, which is an issue which has been investigated by academia, not only as a significant step forward ${ }^{19}$, but also as a blemish which is in need to be polished ${ }^{20}$. In any case, as we will approach in the following sections, the Commission has interpreted the Charter to consider the existence of a general exemption clause ${ }^{21}$.

Thereby, in the establishing instrument of the African regional system we can find a series of important innovations, but also a list of omissions. Nevertheless, the latter will be overcome not only by their own protection and control mechanisms - mostly through cross-fertilization $^{22}$ - but also through legislation - by the adoption of new human rights treaties which complement the Charter; this last issue leads us to the following section.

\footnotetext{
${ }_{16}$ A section in which it is established that "the State shall ensure the elimination of every discrimination against women and also ensure the protection of the rights of women and the child as stipulated in international declarations and conventions".

17 In this regard, See KOIS, L. "Article 18 of the African Charter on Human and Peoples' Rights: A Progressive Approach to Women's Human Rights". East African Journal of Peace and Human Rights, v. 3, p. 92, 1997.

${ }_{18}$ Unlike the European Convention and the American Convention. See art. 15 ECHR; art. 27 ACHR.

19 See MBONDENYI, K. "The African Charter on Human and Peoples’ Rights”. In: MBONDENYI, K. (ed.). International Human Rights and their Enforcement in Africa. Oxford/Nairobi: Law Africa Publishing, 2011. p. 140.

${ }^{20}$ See HEYNS, C. "The African Regional Human Rights System: In Need of Reform?”. African Human Rights Law Journal, v. 1 n. 2, p. 155-174, 2001; SAAVEDRA ÁLVAREZ, Y. "El Sistema Africano de Derechos Humanos y de los Pueblos". Anuario Mexicano de Derecho Internacional, v. 8, p. 671-712, 2008. p. 671-712.

21 See para. 3.1.1. The Court has not clearly decided on this subject. Also, among its peculiarities we point out a series of duties, as a result of the concomitance of the rights and duties of precolonial Africa. Nevertheless, as the Court still had not had the chance to take a stance on this, once again the Commission left these provisions with no practical effects. See para. 3.1.1.

${ }^{22}$ On the inclusion of the concept, See BURGORGUE-LARSEN L.; MONTOYA CESPEDES N., "El diálogo judicial entre la Corte Interamericana de Derechos Humanos y la Corte Europea de Derechos Humanos". In: BANDEIRA, G., URUEÑA, R., y TORRES PÉREZ, A. Protección multinivel de derechos humanos. Barcelona: Red de Derechos Humanos y Educación Superior, 2013. p. 187 and following.
}

\subsection{The African Charter on the Rights and Welfare of the Child}

Within the framework of the African regional system, the first regional instrument exclusively dedicated to the regulation of the rights of minors was enacted: the African Charter on the Rights and Welfare of the Child (henceforth ACRWC or African Charter of the Child) ${ }^{23}$. It was adopted on July 11 th of 1990 and entered into force on November 29th, 1999, currently with 49 Member States ${ }^{24}$.

The decision on its adoption is due to the abovementioned inadequate regulation on the rights of minors in the African Charter, added to the subsequent attempt to provide the specificities of the African continent to the universal treaty on the subject: the UN Convention on the Rights of the Child (henceforth, the CRC) ${ }^{25}$.

As for its structure, the ACRWC has 48 articles, divided in two parts: a first part which gathers a series of children's rights (arts. 1-30), and some duties, (art. 31); a second part dedicated to establishing and regulate the competences of its protection and control mechanism-the African Committee of experts on the rights and welfare of the child - (arts. 32-45), as well as to different technical provisions (arts. 45-48).

Focusing on the first part of the Treaty, even though it is based on the four cornerstone principles of the CRC - non-discrimination; the best interest of the minor; the right to life, survival, and development; parti-

${ }^{23}$ Among the bibliography published on this subject, see CHIRWA, D. M. "The merits and demerits of the African Charter on the Rights and Welfare of the Child". The International Journal of Children's Rights, v. 10, n. 2, p. 157-177, 2002; ADU-GYAMFI J.; KEATING F. "Convergence and Divergence Between the UN Convention on the Rights of Children, and the African Charter on the Rights and Welfare of the Child". Sacha Journal of Human Rights, v. 3, n. 1, p. 47-58, 2013; LLOYD A. "Evolution of the African Charter on the Rights and Welfare of the Child and the African Committee of Experts: Raising the gauntlet". The International Journal of Children's Rights, v. 10, n. 1, p. 179-198, 2002.

${ }^{24}$ The text of the charter is available in HEYNS, C. Human Rights Law in Africa. Leiden: Martinus Nijhoff Pubishers, 2004. p. 143-153. Of the 55 Member States which currently integrate the African Union, only Morocco, the Democratic Republic of Congo, Somalia, South Sudan, Tunisia, and the Sahrawi Arab Democratic Republic are not a part of the African Charter of the Child. So, we are before the second more ratified African regional human rights charter after the African Charter on Human and Peoples' Rights.

25 This omission is partly due to the scarce participation of African states in the Convention drafting process. In the same line of thought, See VILJOEN, F. International Human Rights Law in Africa. Oxford: Oxford University Press, 2012. p. 391-392. 
cipation and respect for their opinions ${ }^{26}$ - the regional treatment offers a greater protection than the universal treaty in several different aspects.

Therefore, a first significant difference we can find is in the definition of a a minor itself, were, contrarily to the $\mathrm{CRC}$, which establishes that one should understand a child as being "every human being below the age of eighteen years unless under the law applicable to the child, majority is attained earlier" ${ }^{27}$, in the ACRWC these is no exception to the age of majority ${ }^{28}$. Similarly, while the first enacts that the best interest of the minor is " $a$ primary consideration", in the regional treaty, the best interest of the minor is "the primary consideration" 29 .

We also appreciate a more rights-based protection in the context of armed conflicts, insofar that the ACRWC categorically establishes that no minor under eighteen years of age shall directly participate in hostilities ${ }^{30}$, and that the State should adopt all "necessary measures" in this regard. As for the CRC, it establishes an age limit of 15 , and refers to the adoption of all "possible measures" to avoid the participation of children in hostilities ${ }^{31}$. Furthermore, the ACRWC, unlike the prior convention, extends the protection afforded to minors under International Humanitarian Law to situations of internal armed conflicts, internal tensions, and uprisings $\mathrm{s}^{32}$.

Equally, a greater protection is provided to the prohibition of marriage, determining the age limit to 18 and requiring official registration documents of marital

\footnotetext{
26 Principles included in articles 3 to 5 of the African Charter of the Child.

27 See article 1 of the CRC.

28 Thus, article 2 of the African Charter of the Child establishes that "for the purposes of this Charter, a child means every human being below the age of 18 years".

29 See, respectively, articles 3.1 of the CRC and 4 of the African Charter of the Child.

30 See, article 22.2 of the African Charter of the Child.

31 See, article 38.2 of the CRC. Albeit, on the 25th of May 2000 the Optional Protocol on the Convention on the Rights of the Child on the Involvement of Children in Armed Conflicts was adopted, which entered into force on February $12^{\text {th }} 2002$, which raises recruitment age to 18 . See, articles 1, 2, 3 y 4 of the Protocol.

${ }^{32}$ See, article 22.3 of the African Charter of the Child; unlike article 38.4 of the CRC. Regarding the topic of armed conflicts, see, CARTES RODRÍGUEZ, J. B. "La protección de la infancia en los conflictos armados en el Sistema Regional Africano de Protección de los Derechos Humanos". In: PÉREZ VILLALOBOS, M. C. (ed.). La protección de la infancia en los conflictos armados. Editorial Universidad de Granada (EUG), 2019. p. 225- 238; FRISSO, G. M. "Crianças-Soldado No Conflito Em Serra Leoa: Direitos Humanos, Direito Internacional Humanitário E/Ou Direito International Penal". Revista de Direito Internacional, v. 9, n. 2, p. 83-91, 2012.
}

unions in order to avoid the evasion of this provision ${ }^{33}$; the rights of internally displaced minors and incarcerated mothers are regulated ${ }^{34}$; a more rights-based protection regarding nationality ${ }^{35}$; and, in the same way as in the African Charter, civil and political rights are equated to economic, social and cultural rights ${ }^{36}$.

However, even though the abovementioned instrument has been defined as "a major contribution to the advancement of regional protection and promotion of international human rights law" ${ }^{37}$, we can also find several critiques, among which, the omission of certain rights which are in the universal treaty - as an example, the right to Access information or the benefit of social security and social insurance ${ }^{38}$; the lack of regulation of the rights of indigenous minors and those of other minorities, even more so taking into account their importance on the continent in question ${ }^{39}$; and, similarly to the African Charter, the existence of claw-back clau$\operatorname{ses}^{40}$. In any case - as we argued in the previous section - these critiques are being safeguarded by the different protection and control mechanisms of the system at stake $^{41}$.

\subsection{The Protocol to the African Charter on Human and Peoples' Rights on the Rights of Women in Africa.}

Also known as the Maputo Protocol due to the Mozambican city where it was adopted don the 1st of July 2003, the Protocol to the African Charter on Human and

\footnotetext{
33 This subject is not regulated in the CRC nor is it included in article 21.2 of the African Charter of the Child.

${ }^{34}$ Likewise, this subject is not regulated in the CRC, but it appears in articles 24.4 to 30 of the African Charter of the Child.

35 Thus, in article 6.3 of the African Charter of the Child, and in contrast to 7 and 8 of the CRC, it is established that "State Parties to the present Charter shall undertake to ensure that their Constitutional legislation recognize the principles according to which a child shall acquire the nationality of the State in the territory of which he has been born if, at the time of the child's birth he is not granted nationality by any other State in accordance with its laws" (my highlight).

${ }^{36}$ Albeit, the Committee, unlike the Commission, has not produced a clear decision on this subject up to now.

37 See MBONDENYI, K. "The African Charter on Human and Peoples' Rights”. In: MBONDENYI, K. (ed.). International Human Rights and their Enforcement in Africa. Oxford/Nairobi: Law Africa Publishing, 2011. p. 228.

38 See articles 17 and 26.1 CRC.

39 Which, by contrast, are present in article 30 of the CRC.

${ }^{40}$ See articles 7 and 8 of the African Charter of the Child, which recognize the rights to expression and association, respectively.

${ }^{41}$ See para. 3.1.1; 3.2.1.
} 
Peoples> Rights on the Rights of Women in Africa (henceforth the Protocol or the Maputo Protocol) came into force on November $25^{\text {th }}, 2005$, with 42 Member States up to June of $2021^{42}$.

As for its structure, the Protocol has 32 provisions, which are not organized in parts or sections. While the first 25 regulate material content, provision number 26 regulates the protection and control mechanisms, and provisions 27 to 32 include different technical rules ${ }^{43}$.

Following the structure of the previous sections, regarding the motivations behind its adoption, firstly, we have a lack of regulation in what concerns the African Charter, secondly, the transition of the Organization for African Unity to the African Union, and among its principles, the express reflection of the promotion gender equality ${ }^{44}$, and thirdly, the scarce implementation of the universal international treaties on the continent specifically, the Convention on the Elimination of All Forms of Discrimination Against Women (henceforth CEDAW) ${ }^{45}$.

As for its material content, we can also appreciate significant progress, among which, the broadening and more precise approach to the concept of discrimination against women with regard to $\mathrm{CEDAW}^{46}$; the recognition for the first time in a treaty of women's rights regarding $\mathrm{HIV} / \mathrm{AIDS}^{47}$; the explicit condemnation of

${ }^{42}$ The text is available in HEYNS, C. Human Rights Law in Africa. Leiden: Martinus Nijhoff Pubishers, 2004. p. 154-158.

43 Among the authors who analysed the content of the Protocol, we can find VILJOEN, F. "An Introduction to the Protocol to the African Charter on Human and Peoples' Rights on the Rights of Women in Africa". Washington and Lee Journal of Civil Rights and Social Justice, v. 16, n. 1, p. 11-45, 2009; MANJOO, R. "Rights of the Vulnerable under the African System Women's Human Rights in Africa". In: SSENYONJO M. (ed.). The African Regional Human Rights System: 30 Years after the African Charter of Human and Peoples' Rights. Leiden/Boston: Martinus Nijhoff Publishers, 2012; MURRAY, R. "Women's Rights and the Organization of African Unity and African Union: The Protocol on the Rights of Women in Africa", in BUSS, D. y MANJI, A. (ed.). International Law: Modern Feminist Approaches. Oxford: Hart Publishing, 2005; NSIBIRWA, M. S. "A brief analysis of the Draft Protocol to the African Charter on Human and Peoples' Rights on the Rights of Women". African Human Rights Law Journal, v. 1, n. 1, p. 40-63, 2001.

${ }^{44}$ See article 4.1) of the Constitutive Act of the African Union.

45 Particularly, the UN Convention on the Elimination of All Forms of Discrimination Against Women, adopted December $18^{\text {th }}, 1979$.

${ }^{46}$ See article 1.f) of the Maputo Protocol; article 1 CEDAW. For a comparison of such provisions, see MBONDENYI, K. "The African Charter on Human and Peoples' Rights”. In: MBONDENYI, $\mathrm{K}$. (ed.). International Human Rights and their Enforcement in Africa. Oxford/Nairobi: Law Africa Publishing, 2011. p. 258-259.

47 See article 14.1.d) and e) of the Maputo Protocol. female genital mutilation and domestic violence ${ }^{48}$; the inclusion of gender equality in respect of inheritance matters ${ }^{49}$; allowing abortion under certain conditions ${ }^{50}$; as well as following the guidelines established in the Charter of the Child, the prohibition of child marriage and of the direct participation in hostilities to minors of under 18 years of age $\mathrm{e}^{51}$.

Likewise, a series rights are recognized to women from certain vulnerable categories, such as widows, older women and those with disabilities ${ }^{52}$; social and economic rights are broadened regarding those foreseen in CEDAW and the African Charter ${ }^{53}$; and there is even a budgetary clause which imposes that States reduce military spending in favour of a greater social development and the promotion of women's rights ${ }^{54}$.

For their part, among the aspects which need to be improved, we can find significant limitations in the transfer of the nationality of people's children ${ }^{55}$, the permissibility of polygamy ${ }^{56}$, or the omission pertaining to certain subjects involving Africanist concepts, for example, by not giving the family the necessary importance, or by not including in the Protocol the concept of peoples' rights nor the concept of cultural rights ${ }^{57}$.

Likewise, the drafting of certain provisions can be improved, particularly those pertaining to protection and control mechanisms. Therefore, it is not specified if - in the process of compliance with the obligation of presentation of periodic reports before the Commission a

48 See, respectively, articles 5.b) and 4.2 of the Maputo Protocol.

49 See, article 21.2 of the Maputo Protocol.

${ }^{50}$ Considering article 14.2.c) of the Protocol, "in cases of sexual assault, rape, incest, and where the continued pregnancy endangers the mental and physical health of the mother or the life of the mother or the foetus".

51 See articles 6.b and 11.4 of the Maputo Protocol.

52 See articles 20 and 22-24 of the Maputo Protocol.

53 Among them, article 15 (right to food security) and 16 (right to adequate housing).

${ }^{54}$ See article 10.3 of the Maputo Protocol.

55 Thus, article 6.h) states that "a woman and a man shall have equal rights with respect to the nationality of their children except where this is contrary to a provision in national legislation or is contrary to national security interests" (my highlight); also considering that discriminatory legislation on this subject still exists in numerous African states.

56 See article 6.c of the Maputo Protocol.

57 Moreover, on this last subject, the succinctness of article 17. On this subject, see REBOUCHE, R. 'Labor, Land and Women's Rights in Africa: Challenges for the New Protocol on the Rights of Women”. Harvard Human Rights Journal, v. 19, n. 1, p. 250, 2006; and CHIRWA D. M. "Reclaiming (Wo)manity: the Merits and Demerits of the African Protocol on Women's Rights". Netherlands International Law Review, v. 53, n. 1, p. 91, 2006. 
single document including not only the advancements of the implementation of the African Charter and the of the Protocol suffices or if it the presentation of two independent documents is required. Furthermore, it is also not specified if the Commission and the Court have ratione materiae jurisdiction over the Protocol. The first of these issues was clarified through the approval by the Commission in 2010 of guiding principles on periodic reports ${ }^{58}$; as for the second issue, regarding APDF \& IHRDA vs Republic of Mali, the Court understood that violations of the rights established in the Protocol as included within its scope of action ${ }^{59}$, even though the Commission has not yet produced a decision on this matter.

\subsection{Other treaties of the system}

Along with the above-mentioned texts, first under the auspices of the OAU and later of the African Union, a series of treaties were adopted with a common characteristic - broadly, and until the time of the elaboration of this paper- their limited supervision, and thereby, implementation.

The first is the OAU Convention governing the Specific Aspects of Refugee Problems in Africa (henceforth the OAU Convention on Refugees). Adopted on September 10th, 1969, in force since January 20th of 1974 , it was the first treaty enacted within the OAU framework regarding human rights, previously included in the African Charter. It is a short text which, among its innovations, involves the broadening of the concept of refugee in comparison to the $1951 \mathrm{UN}$ Convention ${ }^{60}$,

58 These guiding principles can be consulted at: https://www. achpr.org/statereportingproceduresandguidelines (Consulted on 15.06.2021), and in those which specify that the provided information can be delivered in one single document.

59 See App. 046/2016, APDF \& IHRDA vs. Republic of Mali, Judgments on Merits and Reparations, (11 May 2018), paras. 9 and 27. The Protocol only specifies that the interpretation of its articles matches the interpretation by the Court and - on a transitory basis - to the Commission while it was not yet in function. See articles 27 to 32 of the Protocol.

${ }^{60}$ Thus, considering article 1.2 of the OAU Convention, "the term refugee shall also apply to every person who, owing to external aggression, occupation, foreign domination or events seriously disturbing public order in either part or the whole of his country of origin or nationality, is compelled to leave his place of habitual residence in order to seek refuge in another place outside his country of origin or nationality". In fact, such a definition has been a model for later instruments. To this effect, see ARBOLEDA, E. "The Cartagena Declaration of 1984 and its Similarities to the 1969 OAU Convention: A Comparative Perspective". International Journal of Refugee Law, v. 7, p. 87-101, 1995. now understood ass including situations stemming from natural disasters ${ }^{61}$. Nevertheless, the rights which are afforded are limited and a mechanism of protection and control is not established in its text ${ }^{62}$.

Secondly, we encounter the African Union Convention for the Protection and Assistance of Internally Displaced Persons in Africa, adopted on October 23rd, 2009, which entered into force on December 6th, 2012. Following the pattern of the previous convention, it stands out for including disasters - whether they are natural disasters or disasters of human origin, namely, those that cause displacement ${ }^{63}$, and for being one of the few human rights treaties which currently impose certain obligations directly to armed groups ${ }^{64}$. Notwithstanding, some of the provisions are not as precise as would be necessary, and the surveillance mechanisms are practically inexistent ${ }^{65}$.

Thirdly, we have the African Charter on Democracy, Elections and Governance. Adopted January 30th, 2007, and in force since February 15th, 2012, it intends to approach from a comprehensive perspective the establishment and the consolidation of a democratic regime, regarding election procedures, unconstitutional changes in governments, rule of law, and to the civilian control

${ }^{61}$ In this context, see VILJOEN F. International Human Rights Law in Africa. Oxford: Oxford University Press, 2012. p. 243.

${ }_{62}$ For a more detailed analysis of this instrument, with a focus on its innovations and shortcomings, see. SHARPE, M. "The 1969 African Refugee Convention: Innovations, Misconceptions, and Omissions". McGill Law Journal, v. 58, n. 1, p. 95-147, 2012; OKOTHOBBO, G. Thirty years on: A legal review of the 1969 OAU Refugee Convention Governing the Specific Aspects of Refugee Problems in Africa. Refugee Survey Quarterly, v. 20, n. 1, p. 79-138, 2001.

${ }^{63}$ See article 1.k) AU Convention for Internally Displaced People.

${ }^{64}$ See article 7 of the AU Convention for Internally Displaced People, Article 7. Connected to this issue, see ÍÑIGO ÁLVAREZ, L. Towards a regime of responsibility of armed groups in international law. Cambridge: Intersentia, 2019.

${ }^{65}$ For a detailed analysis of the Convention see MULUGETA ABEBE, A. "The African Union Convention on internally displaced persons: Its codification background, scope, and enforcement challenges". Refugee Survey Quarterly, v. 29, n. 3, p. 28-57, 2010; KIDANE, W. "Managing Forced Displacement by Law in Africa: The Role of the New African Union IDPs Convention". Vanderbilt Journal of Transnational Law, v. 44, n. 1, p. 1-85, 2011. In any case we must mention that, from 2004 onwards, after the creation of the Special Rapporteur on Refugees, Asylum Seekers, Migrants and Internally Displaced People under the auspices of the Commission, State Parties should incorporate the advancements in this matter in their respective periodic reports. See https://www.achpr.org/specialmechanisms/detail?id=5 (Date of consultation: 15.06.2021). In their turn, regarding the Court, even though it still has not decide don any of the provisions of the referred Treaty, we understand that it would be included in its broad ratione materiae competence. See para. 3.2.1. 
of the armed forces ${ }^{66}$. For their part, albeit within the framework of the Commission - the same can be said for the rest of the treaties referred to in this section: up to now, there is not a communication which recognizes the violation of some of its rights - and the question remains regarding if the quasi-judicial mechanism will consider it included within its ratione materiae competence; to the contrary, the Court did recognize the subject Actions Pour La Protection Des Droits De L'homme (APDH) v. Republic of Cote d'Ivoire, the violation of the provisions of the Charter on Democracy, as well as the principle of equality before the law and the need to establish impartial and independent electoral bodies ${ }^{67}$. And this even though the Treaty does not expressly establish the Court as its protection and control mechanism ${ }^{68}$.

Lastly, and besides the three abovementioned treaties, we can find many other treaties which are in force adopted under the auspices of the OAU/AU and, to a greater or lesser degree, pertaining to human rights issues: among them, the African Union Convention on Preventing and Combatting Corruption, the African Cultural Charter, and the African Convention on the Conservation of Nature and Natural Resources, or the Charter for African Youth ${ }^{69}$.

\footnotetext{
${ }^{66}$ For a more detailed analysis of the referred treaty see GLEN, P. J. "Institutionalizing democracy in Africa: a comment on the African Charter on Democracy, Elections and Governance". African Journal of Legal Studies, v. 5, n. 2, p. 119-146, 2012.

${ }^{67}$ Foreseen respectively in articles 10.3 and 17 of the African Charter on Democracy. See App. 001/2014, APDH vs. Republic of Cote d'Ivoire, Judgments on Merits, (18 November 2016), paras. 153.5 and 6.

${ }_{68}$ This is due to the ample ratione materiae jurisdiction that the constitutive Protocol of the Court attributes to it. For a deeper knowledge of this issue, see para. 3.2.1. In its turn, it is true that the AU Peace and Security Council decided to suspend the membership of certain States of the International Organization due to unconstitutional changes of government - the latter being Mali in June of 2021- but in their declarations they only tend to invoke article 30 of the AU Constitutive Act, and not the respective provision of the African Charter on Democracy (art. 25).

${ }^{69}$ The text, the date of adoption and of entering into force of the treaties referred to in the present section can be consulted at https://au.int/en/treaties (Consulted on 15.06.2021). Along with the treaties currently in force, today we can see that there are two Protocols to the African Charter waiting to obtain the fifteen required ratifications: the Protocol to the African Charter on Human and Peoples' Rights on the Rights of Older Persons, adopted January 31st2016, and the Protocol to the African Charter on Human and Peoples' Rights on the Rights of Persons with Disabilities, adopted January $29^{\text {th }}, 2018$. In such treaties, it is established that interpretation is under the auspices of the Commission, while the African Court oversees its application. See, respectively, articles 22 to 34 . However, we do consider regulation is insufficient in this regard due to the well-known fact that it is not possible to disconnect the inter-
}

After this analysis of the main treaties of the regional African system, we will follow by examining the different protection and control mechanisms which have been created.

\section{Protection and control mechanisms}

In contrast with the cornerstone treaties of the European and Interamerican systems ${ }^{70}$, the African Charter on Human and Peoples' Rights only foresees the creation of one quasi-judicial mechanism: the African Commission on Human and Peoples' Rights (henceforth ACHPR or the Commission) $)^{71}$, which is accompanied by a second quasi-judicial mechanism due to the African Charter of the Child: the African Committee of Experts on the Rights and Welfare of the Child (henceforth, the Committee). Thus, it was necessary to wait until 1998 for the adoption of a constitutive treaty regarding a judicial body in the heart of the African system and in the process of its strengthening, which started to work properly in the decade of 2000. Further on we will analyse them, as well as the reform process which is taking place in this context.

\subsection{Quasi-judicial mechanisms.}

\subsubsection{African Commission on Human and Peoples' Rights}

As we have pointed out in previous sections, the second part of the African Charter is dedicated to the composition and the functions of the Commission, and

pretation of the treaty from its application. In this context, see, Cfr. LÓPEZ MARTÍN, A. G. "La doctrina del consejo de estado sobre los efectos jurídicos de los dictámenes de los comités de derechos humanos de Naciones Unidas". In: FERNÁNDEZ DE CASADEVANTE ROMANÍ, C. (coord.). Los efectos jurídicos en España de las decisiones de los órganos internacionales de control en materia de derechos humanos de naturaleza no jurisdiccional. Madrid: Dykison, 2020.

${ }^{70}$ See articles 19 and ss. ECHR; 52 and ss. ACHR.

71 The African Commission on Human and People's Rights, a human rights body, should not be confused with the AU Commission, which acts as a technical secretariate for the entire International Organization. In its turn, the Assembly of Heads of State and Government is the highest body of the AU and is aided by another body in the performance of its duties, to which we will also refer to, the Executive Council, composed mostly of Ministers of Foreign Affairs from the Member States. 
these rules have been complemented by 1988 Procedure Rules, revised in 1995, 2010 and $2020^{72}$, as well as certain Principles ${ }^{73}$.

On the 2nd of November 1987 the first regular session of the Commission took place, establishing its permanent headquarters in Banjul (Gambia) from 1989 onwards. As for its composition, the ACHPR has eleven members of renowned prestige, elected by the Assembly of Heads of State and Government of the AU from a list previously elaborated by the Member States of the African Charter on Human and Peoples' Rights $^{74}$. The mandate lasts for 6 years and includes the possibility of a re-election ${ }^{75}$. In their turn, the members of the Commission should elect the President and the Vice president, who will serve two-year terms, also with the possibility of re-election ${ }^{76}$.

Before going into the functions of the ACHPR not only protective functions but also promotional functions - we consider it is important to say that, besides the Commission's limitations in terms of budget and functions which it has had to deal with, it has been characterized by maintaining a protection-based performance regarding human rights on the continent, while dealing with some of the most significant shortcomings of the African Charter ${ }^{77}$.

Looking into the protection-based attributions of the Commission, the ones which have undoubtedly had a greater impact are those stemming from the communications which were presented. In this regard, the Charter foresees the two types of communications:

\footnotetext{
72 The 2020 Procedure Rules can be consulted at: https://www. achpr.org/legalinstruments/detail?id=72 (Date of consultation: 15.06.2021). A detailed analysis of the Commission can be found in MURRAY, R. The African Commission on Human and Peoples' Rights and International Law. Oxford: Hart Publishing, 2000; VILJOEN F. et. al. A Guide To The African Human Rights System: Celebrating 30 Years Since the Inauguration of the African Commission on Human and Peoples' Rights. Pretoria, Center for Human Rights University of Pretoria, University Law Press, 2017.

73 Among them, the Guidelines for the periodic national reports of April 14, 1984; Guidelines for the presentation of reports on economic, social and cultural rights of State Parties in the African Charter on Human and Peoples' Rights, of 24 October 2011; Guidelines for the presentation of Communications, 1 January 2000.

${ }^{74}$ See articles 31 and 33 of the African Charter.

75 See article 36 of the African Charter.

${ }^{76}$ See article 42 of the African Charter. We would like to point out that the Commission should organize four regular sessions per year. See Rule 28.1 of the Commission Procedure Rules.

77 The limited Budget which was granted in 2019 can be consulted at Doc. Assembly/AU /Dec.699(XXXI), p. 2.
}

interstate communications and individual communications $^{78}$.

As for the former, in its over thirty years of existence, only one was analysed by the Commission: the one pertaining to the case Democratic Republic of Congo v. Burundi, Rwanda and Uganda, where it was determined that, during the occupation of the Democratic Republic of Congo from 1998 to 1999 by the armed forces of Burundi, Ruanda and Uganda, several violations were committed of human rights foreseen in the African Charter, among which, the murder of civilians, kidnappings and cases of sexual violence ${ }^{79}$.

On the other hand, the number of individual communications to the Commission which are known of until now are over $200^{80}$. An extensive interpretation by the Commission of the African Charter contributed to this, understanding that communications can be presented by an individual, a group of individuals and NGOs, whether in their own name or in the name of the victim ${ }^{81}$.

As for their content, we can verify that they have been a more than significant evolution in what concerns the thoroughness and the legal robustness of their rationale, as well as a protective interpretation of the rights foreseen in the Charter.

78 Individual communications are regulated under articles 54 to 55 of the African Charter and in Rules 115-126 of the Commission Procedure Rules. In their turn, interstate communications can be classified as being two types of communications: the negotiationcommunication and the complaint-communication, the former being regulated, respectively, in article 47 of the Charter and in rule 108 of the Commission Rules; and the latter in article 47 of the Charter, developed under rules 109-114 de of the Commission Rules.

79 See African Commission, Communication 227/99, Democratic Republic of Congo v. Burundi, Rwanda, Uganda, (29 May 2003), p. 25.

${ }^{80}$ See https://www.achpr.org/communications and http://caselaw.ihrda.org/body/acmhpr/ (Consulted on: 15.06.2021).

81 See 115.1; 115.2.a of the Commission Procedure Rules. In this context, we should Communication 277/03, Spilg and Mack \& Ditshwanelo (on behalf of Leblohonolo Bernard Kobedi) 1 . Botswana, (12 October 2013), in which the Commission established that "the African Commission has, through its practice and jurisprudence, adopted a generous access to its Complaint Procedure. It has adopted the actio popularis principle, allowing everyone the legal interest and capacity to file a Communication, for its consideration. For this purpose, non-victim individuals, groups and NGOs constantly submit Communications to the African Commission. More so, the African Commission, has $[\ldots]$ encouraged the submission of Communications on behalf of victims of human rights violations, especially those who are unable to represent themselves", para. 76. On the other hand, see the succinct article 55.1 of the African Charter, which provides a legal basis for the presentation of individual communications. 
Regarding this last point, the Commission has taken on a restrictive interpretation of the abovementioned claw-back clauses, stating the following:

"The Commission's jurisprudence has interpreted the so-called claw-back clauses as constituting a reference to international law, meaning that only restrictions on rights which are consistent with the Charter and with States Parties' international obligations should be enacted by the relevant national authorities" (our highlight) ${ }^{82}$.

Additionally, it did, in fact, incorporate a general exemption clause attending to article 27.2 of the African Charter $^{83}$; it recalled that the individual duties which are listed do not in any way legitimate governments to additionally restrict any of the recognised rights and freedoms ${ }^{84}$; in the face of the silence of the Charter, it granted provisional measures ${ }^{85}$ and remedial measures, the latter being more and more detailed ${ }^{86}$; and it has resorted to articles 60 and 61 to develop a cross-fertilization of ideas regarding other human rights systems with the purpose of a more protectionist interpretation of the principles of the Charter ${ }^{87}$.

${ }_{82}$ See Communication 275/03, Article 19 v. Eritrea, (30 May 2007), para. 92.

83 Article which establishes that "the rights and freedoms of each individual shall be exercised with due regard to the rights of others, collective security, morality and common interest". See Communication 279/03-296/05, Sudan Human Rights Organisation \& Centre On Housing Rights And Evictions (COHRE) v. Sudan, (27 May 27 2009), paras. 165-166.

84 While stating that "the only legitimate reasons for limitation of the rights and freedoms of the African Charter are found in article 27.2, that is, that the rights of the Charter "shall be exercised with due regard to the rights of others, collective security, morality and common interest" (our highlight). See Communication 279/03-296/05, Sudan Human Rights Organisation \& Centre On Housing Rights And Evictions (COHRE) v. Sudan, (27 May 27 2009), para. 165.

${ }^{85}$ See v. gr. Communication 250/02, Liesbeth Zegveld and Mussie Ephrem v. Eritrea; Communication 240/01 Interights et al. (on behalf of Mariette Sonjaleen Bosch) $v$. Botswana. Currently, the possibility of adopting provisional measures is expressly established in Rule 100 of the Commission Procedure Rules.

${ }^{86}$ Among its jurisprudence, one can find restitution, satisfaction, and compensation measures, as well as guarantees of non-repitition. Regarding the latter, see, Communication 426/12, Agnes UwimanaNkusi \& Saidati Mukakibibi v. Rwanda, (16 April 2021), para. 228. iv. As an example of a restitution measure, see Communication 416/12, Jean-Marie Atangana Mebara v. Cameroon, (18 May 2016), para. 145.1; and, for satisfaction measures, see Communication 379/09, Monim Elgak, Osman Hummeida And Amir Suliman (Represented By FIDH And OMCT) v. Sudan, (10 March 2015), para. 142. iii. b.

87 See Communication 355/07, Hossam Ezzat \& Rania Enayet (represented by Egyptian Initiative for Personal Rights \& INTERIGHTS) v The Arab Republic of Egypt, (28 April 2018), referring to the jurisprudence of the UN Human Rights Committee (para. 141) and the International Court of Justice (para. 171); or on the issue of Com-
Moreover, albeit, on one hand, the Commission understood that ECSR are subject to a progressive realization clause ${ }^{88}$, on the other, it also affirmed the existence of a series of minimal essential obligations, the prohibition of retrogressive measures, and the respect for the principle of non-discrimination regarding these rights ${ }^{89}$.

In their turn, while most communications revolve around allegations of civil and political rights allegations, the most significant were the ones concerning economic, social, cultural and peoples' rights, among which we point out the Endorois and Ogoniland issues; and, where the Commission articulates certain new rights regarding certain indigenous peoples in relation to the African Charter - among which, the right to land or the right to food ${ }^{90}$.

Nevertheless, the Commission suffers a series of limitations, among which we point out, besides the budgetary limitations, those regarding confidentiality requirements pertaining its work until the Assembly of Heads of State and Government of the AU considers them ${ }^{91}$.

munication 416/12, Jean-Marie Atangana Mebara v. Cameroon, (18 May 2016), referring to the jurisprudence of the ECHR (para. 99) and the United Nations Working Group on Arbitrary Detention (paras. 121 and 139).

${ }^{88}$ See Communication 241/01, Purohit and Moore v. The Gambia, (29 May 2003), para. 84.

89 Its most detailed pronouncement on this subject is in the Guidelines and principles on economic, social and cultural rights of the African Charter on Human and Peoples' Rights, of 24 October 2011.

90 See Communication 276/03, Centre for Minority Rights Development and Minority Rights Group (on behalf of Endorois Welfare Council) v. Kenya, (25 November 2009); Communication 155/96, Social and Economic Rights Action Center (SERAC) and Center for Economic and Social Rights (CESR) v. Nigeria, (27 October 2001). For an analysis of these pronouncements see LYNCH, G. "Becoming indigenous in the pursuit of justice: The African Commission on Human and Peoples' Rights and the Endorois" African Affairs, v. 111, n. 442, p. 24-45, 2012; COOMANS, F. "The Ogoni Case Before the African Commission on Human and Peoples' Rights". The International and Comparative Law Quarterly, v. 52, n. 3, p. 749-760, 2003. Among the bibliography published on this subject, see VIEGAS REICHARDT, F.; EDUARDO GARAVELLO, M. E. "Quando Habitar Corresponde Ao Direito Humano À Alimentação". Revista de Direito Internacional, v. 14, n. 1, p. 68-79, 2017; CAMERA, S.; WEGNER, R. "Dreito humano à alimentação, (in)segurança alimentar e desenvolvimento: os desafios à realização progressiva na América Latina". Revista de Direito Internacional, v. 14, n. 1, p. 21-34, 2017.

${ }^{91}$ See article 59 of the African Charter. Thus, as we see it, certain communications which are on its webpage are not available, to comply with the referred confidentiality requirement. Likewise, in contrast with the Court, there is no updated registration of the degree of compliance with the adopted decisions. 
Furthermore, taking into account the little involvement (and interest) from the AU political bodies in the work around supporting the Commission, it becomes evident in two aspects; on one hand, the inaction before the procedures stemming from grave and mass human rights violations, in conformity with article 58 of the African which led the Commission to follow its regular procedure also in these cases; and, on the other, concerning the follow up of the communications, which is ultimately required from the AU political bodies - specifically, from the AU Assembly and the Executive Council ${ }^{92}$-and here we find an obvious stagnancy ${ }^{93}$, which results in a scarce degree of compliance with their decisions $^{94}$.

In its turn, considering article 62 of the African charter, State Parties should present a biennial report on implementation and compliance. Even though the Charter does not point out the body in charge of presentation and evaluation, the Commission requested that the Assembly of Heads of State and Government gave it that function ${ }^{95}$. Nevertheless, of the 54 Heads of State, six still have not presented a single report, and only two States- Kenia and Swaziland - presented all their respective reports ${ }^{96}$. It must be added to this that the guidelines for the presentation of reports show significant shortcomings ${ }^{97}$, and that the final Observations

92 See Rule 125.8-10 of the Rules of Procedure of the Commission. ${ }^{93}$ In the reports of the Executive Council and of the Assembly there are no specific references to such questions. See https:// au.int/en/decisions/council y https://au.int/en/decisions/assembly (Consulted on 15.06.2021).

${ }^{94}$ See VILJOEN, F.; LOUW, L. "State Compliance with the Recommendations of the African Commission on Human and Peoples' Rights, 1994- 2004". American Journal of International Law, v. 101, n. 1, p. 1-34, 2007.

${ }^{95}$ See African Commission, First Activity Report of the African Commission on Human and Peoples' Rights, 28 April 1988, Annex IX.

${ }^{96}$ On their part, the States which still have not presented any report are the following: Guinea-Bissau, Equatorial Guinea, the Comoros, San Tomé and Príncipe, Somalia, and South Sudan. Information available at: https://www.achpr.org/statepartiestotheafricancharter (Consulted on 15.06.2021).

${ }^{97}$ The Guidelines on the presentation of state reports were adopted in 1989, having been classified by the doctrine as beginning too extensive and complex; which stemmed from its revision at the end of the 90's. Notwithstanding, the latter were qualified as being too succinct, and currently they are even not available on the Commission website. Although it is true that specific Guidelines have been adopted to supervise compliance with certain rights in the Charter, for example, in 2011, those on economic, social, and cultural rights. The different Guidelines are available at: https://www.achpr. org/resources (Consulted on: 15.06.2021). Regarding doctrinal pronouncements, See QUASHIGAH, K. "The African Charter on Human and Peoples' Rights: Towards a more effective reporting per se which were produced were too lax in the compliance follow up ${ }^{98}$.

Lastly, along with the interpretation of the Charter and the Maputo Protocol through general observations, resolutions and principles ${ }^{99}$ and the accomplishment of certain promotional activities such as organizing conferences and seminars or visits to certain States, ${ }^{100}$, it is important to point out that, due to an extensive interpretation of articles 45 and 46 of the African Charter, three types of special mechanisms were created in the heart of the Commission: special rapporteurs, working groups and committees, which are distinguishable according to their members ${ }^{101}$.

Notwithstanding, such a protective and extensive interpretation of its functions was stopped from 2015 onward, due to the granting of observer status before the Commission to the NGO "Coalition of African Lesbians (CAL)". As a result of such a decision, the Executive Council of the AU ordered that the status in question got taken away, stating that the quasi-judicial body should comply with that mandate, as its independence is only "functional in nature and not independence from the same organs that created the body" ${ }^{102}$. After

mechanism". African Human Rights Law Journal, v. 2, n. 2, p. 296-300, 2002; EVANS, M.; MURRAY, R. “The State Reporting Mechanism of the African Charter”. In: EVANS, M., y MURRAY, R. (ed.). The African Charter on Human and Peoples' Rights: The System in Practice, 1986-2006. Cambridge: Cambridge University Press, 2008. p. 63.

${ }^{98}$ See MUGWANYA, G. W. "Examination of state reports by the African Commission: A critical appraisal". African Human Rights Law Journal, v. 1, n. 2, p. 278, 2001.

99 These instruments can be consulted at: https://www.achpr.org/ resources (Consulted on: 15.06.2021).

100 The different fostering activities carried out by the Commission are compiled in different activity reports available on the Commission webpage, see https://www.achpr.org/activityreports (Consulted on: 15.06.2021).

101 Therefore, among the first group are the rapporteurs on women's rights; prisons and detention conditions; freedom of expression and access to information; human rights defenders; as well as refugees, asylum seekers, internally displaced people, and migrants in Africa. Among the second group, we have the Committee on the prevention of torture and the Committee on the protection of people living with HIV and Those at Risk, Vulnerable to and Affected by HIV. And, among the third group, the Working Group on Economic, Social and Cultural Rights; on the death penalty, extrajudicial, summary, or arbitrary executions and enforced disappearances; on the rights of older persons and of people with disabilities; and on extractive industries, the environment and human rights violations. Such mechanisms were created between 1996 and 2010. The work carried out by each one of them can be consulted at: https://www. achpr.org/specialmechanisms (Consulted on: 15.06.2021).

102 See Decision EX.CL/Dec.1015(XXVIII) of June 2015. 
an attempt of misdirection ${ }^{103}$, the status ended up being taken away from that NGO. Furthermore, in the reform of the 2020 Procedural Rules we can observe that some provisions which are inserted in this paragraph limit the attributions of the Commission and to strengthen its subordination to the AU political organs ${ }^{104}$.

\subsubsection{African Committee of Experts on the Rights and Welfare of the Child}

The African Charter on the Rights and Welfare of the Child focuses chapters two and three on the creation and regulation of the functions of a new quasi-judicial mechanism: the African Committee of Experts on the Rights and Welfare of the Child ${ }^{105}$; and these provisions are complemented by the Revised Procedural Rules and by a series of Guidelines ${ }^{106}$.

Its first regular session took place in 2002 in Ethiopian capital, nevertheless, until now, a headquarters for the Committee has not yet been established. As for its composition, just like the Commission, it has eleven members of renowned prestige elected by the Assembly of Heads of State and Government of the AU. Whereas its mandate is of five years, with the possibility of re-election ${ }^{107}$. Its President and two Vice-presidents are elected by the members of the Committee for a two-year period, also with the possibility of re-election ${ }^{108}$.

Before going into their functions, we must mention that even though we mentioned the limitations it faces regarding the functions and budget of the Commission, these are even more pressing in what concerns the Committee, of which, moreover, there is no extensive knowledge of its own existence and responsibilities on the continent.

\footnotetext{
103 Which resulted in a new Resolution on the part of the Executive Council, see Decision EX.C/Dec.995(XXXII) of January 2018 and Decision EX.CL/Dec.1015(XXXIII) and June 2018.

104 See the inclusion of Rule 11 about the submission of the Commissioners to the AU Code of Conduct. Likewise, see 3.2.1. regarding new access limitations from the Commission to the Court.

105 See articles 32-45 ACRWC, which are inserted in the Second Part of the Charter.

106 The Procedural Rules were adopted in 2002 and later revised in 2018. In their turn, among the latter, we have the Revised Guidelines for the Presentation of Communications and the Revised Guidelines for the Analysis of Communications, both adopted in 2014.

107 See articles 33-35 ACRWC.

108 See Rules 6-8 of the Revised Procedural Rules.
}

Thus, even though the African Charter gives it ample ratione personae functions, and is authorized to receive communications from States, individuals, groups of individuals, NGOs, as well as bodies and specialized agencies of the AU and the $\mathrm{UN}^{109}$, and while the Committee has followed a protective interpretation of the provisions of the Charter in the resolution of cases ${ }^{110}$, greatly based on a cross fertilization with the Commission and the bodies of other systems ${ }^{111}$, up to now only six communications on the merits were known of in its almost 20 years of existence ${ }^{112}$; no updated information on the degree of compliance was provided ${ }^{113}$.

The same line of thought can be followed regarding the periodic reports that need to be presented to the States that are party to the Charter every three years ${ }^{114}$, as six States did not present any report - Botswana, Cape Verde, Gambia, Equatorial Guinea, Djibouti-and only nine presented a second report ${ }^{115}$. In the same way, on one hand, some of the reports which were presented were evaluated by the Committee three years after this presentation $^{116}$, while, on the other hand, we can find

109 See article 44.1 ACEWC. Section 1.1 of the Revised Directives on the Presentation of Communications. Albeit, unlike the Commission, more restrictive requirements are established Before the Committee for the presentation of communications by NGOs, as it is required that they have a recognized status by the $\mathrm{AU}$, a Member State or the UN.

${ }^{110}$ For example, by considering the requirement of the age of majority established in article 22 of the African Charter of the Child included not only in - forced - recruitment - but also in - voluntary - enlisting. See Nr. 001/Com/001/2005, Michelo Hunsungule and others (on behalf of children in northern Uganda) $v$. The government of Uganda, (April 2013), para. 58.

111 See Communication Nr. 005/Com/001/2015, African Centre of Justice and Peace Studies (ACJPS) and People's Legal Aid Centre (PLACE) v. the Government of Republic of Sudan, (May 2018), paras. 37-38, 43, 45, 61, 78, 83, 94 y 97.

112 The number of those presented rose to 16 , according to the available information. They can be consulted on: https://www. acerwc.africa/table-of-communications/ (Date of consultation:15.06.2021).

113 See the omission of such an extreme in the reports on the biennial sessions celebrated by the Committee, available at: https:// www.acerwc.africa/sessions/ (Date of consultation:15.06.2021).

114 See article 43.1.b) African Charter of the Child. Similarly, paragraph a) of the referred provision establishes that the deadline for the presentation of the initial report is of two years counting from the entry into force of the Charter regarding the State in question.

115 Burkina Faso, Cameroon, Guinea, Kenia, Nigeria, Niger, Ruanda, South Africa and Tanzania. Information available at: https:// www.acerwc.africa/initial-and-periodic-reports/ (Consultation date:15.06.2021).

116 For example, in the cases of Burkina Faso and Tanzania, which were States that presented the initial reports in 2006 and were not evaluated until around the end of 2009. See https://www.acerwc. 
States regarding which the final Observations were issued by the Committee are not available nowadays, even though they presented their respective reports years ago; que question remains on whether they are still under confidentiality or if the reports simply have not yet been evaluated ${ }^{117}$.

In its turn, even though it is true that the Committee adopted five general Comments, developing and specifying different provisions of the African Charter of the Child, namely, child marriage, name and nationality, incarcerated parents, minors in armed conflicts, State Party obligations and duties of minors ${ }^{118}$, and that, like the Commission, it was given the task of creating different special mechanisms, particularly special rapporteurs and working groups ${ }^{119}$; regarding the latter, the adopted resolutions or the work that has been developed over the last years do not even show up on the Committee website $^{120}$.

Hence, following what was explained above, we are faced with two options: strengthening the Committee with funds and staff, and making its existence and functions known throughout the continent; also, as a second option, transferring the functions of the Committee to the Commission, increasing their funds, bien, and investing in a single - but robust - quasi-judicial mechanism within the system.

africa/concluding-observations/ (Date of consultation: 15.06.2021) 117 This is the case of the Libyan State, which presented its initial report in the year of 2010. See https://www.acerwc.africa/concluding-observations/ (Date of consultation: 15.06.2021).

118 The date of the adoption of the text in each of the General Comments can be consulted at: https://www.acerwc.africa/generalcomments/ (Date of consultation: 15.06.2021).

119 Currently, 10 of the former and 3 of the latter. The ten special rapporteurs created due to Rule 58 of the revised procedural Rules cover the following subjects: "violence against children; children and armed conflict; birth registration, name and nationality; child marriage and other harmful practices; child participation; children in vulnerable situations; health, welfare and development; children on the move; children in conflict with the law parental responsibilities and child responsibilities; and education". In its turn, also due to Rule 58, the following working Groups were created: "Working Group on Children's Rights and Business; Working Group on Children's Rights and Climate Change; and Working Group on Implementation of Decisions and Recommendations". See https://www. acerwc.africa/about/ (Date of consultation: 15.06.2021).

120 Among other tasks carried out by the Committee we have State visits to supervise the implementation of the African Charter of the child. Up to now, they were carried out in Tanzania, South Sudan, the Central African Republic and the Sahrawi Arab Democratic Republic, see https://www.acerwc.africa/missions-country-visits/ (Consultation date: 15.06.2021).

\subsection{Judicial mechanisms}

\subsubsection{The African Court on Human and Peoples' Rights}

As we have pointed out in the first section of this paragraph, it was not until June 10th 1998, when the additional Protocol was adopted, that a judicial body was established in the regional system: the Protocol to the African Charter on Human and Peoples' Rights $r$ Regarding the Establishment of an African Court on Human and Peoples' Rights (henceforth the Protocol to the ACHPR), which came into force on the $25^{\text {th }}$ of January 2004, after obtaining the fifteen required ratifications $^{121}$. Therefore, almost forty years had to pass for the claims which were gathered in the "Lagos Law" were set out in a binding text ${ }^{122}$.

Although currently it is obvious that the African Court on Human and Peoples' Rights contributed to the consolidation and the strengthening of the regional system, its creation and implementation was slow to say the least. Therefore, it would not be up to 2006 when the eleven magistrates of the Court were elected ${ }^{123}$; and it was only attributed a permanent headquarters in Tanzania (Arusha) in 2008; its Regulation was drafted and then modified in 2010 and in $2020^{124}$; and it finally received its first case - Michelot Yogogombaye v. the Republic of Senegal - which was resolved on December $15^{\text {th }} 2009^{125}$. However, for the first decision on the merits of a case

121 See article 34.3 of the Protocol of the African Court on $\mathrm{Hu}$ man and Peoples' Rights. The Protocol which currently has 30 State Parties can be consulted at: https://au.int/en/treaties (Consultation date: 15.06 .2021$)$.

122 We recall that in this document which was drafted in 1961 already called for the creation of a human rights judicial body on the continent. See para 1. In their turn, among the authors which analysed the functioning of the Court we have HANFFOU NANA, S. La Cour africaine des droits de l'homme et des peuples: étude à la lumière de l'expérience européenne. Saint Denis: Editions Publibook, 2016; CARTES RODRÍGUEZ, J. B. "El Tribunal Africano de Derechos Humanos y de los Pueblos: ¿Hacia un África en Paz?”. Anuario Mexicano de Derecho Internacional, v. 17, p. 251-289, 2017.

123 Elected by the Assembly of Heads of State and Government of the AU from a list of candidates elaborated by State Parties in the Protocol. See article 11-13 of the Regulation of the African Court on Human and Peoples' Rights.

124 See Regulation of the African Court on Human and Peoples' Rights adopted 1 September 2021, available at: http://www.africancourt.org/ (Date of consultation: 15.06.2021).

125 See App. 001/2008, Michelot Yogogombaye v. Republic of Senegal, (15 December 2009). 
Tanganyika Law Society, Legal and Human Rights Centre, Rev. Christopher Mtikila v. United Republic of Tanzania, we had to wait until $2013^{126}$.

One of the specificities which are most pointed out by the African Court on Human and Peoples' Rights is the vast ratione materiae competences which its Regulation attributes it on a procedural level. Thus, concerning article 3, the Court can interpret and apply not only the African Charter on Human and Peoples' Rights and all the other treaties of the system, but also any "other instrument pertaining to human rights which is ratified by the State in question."; this was used by the Court to mainly apply the most protectionist provisions in the universal system, while following a pro homine modus operandi, but also regarding other principles such as those pertaining to the International Covenant on Civil and Political Rights ${ }^{127}$.

Moreover, the Court declared itself competent to analyse the violations of the provisions in those instruments that, without having been or having the possibility of being ratified by the State itself (the latter would be the case of the declarations), have developed into customary law. Nevertheless, up to now, this jurisprudential line of thought has been adopted on a not so solid legal basis regarding article 15.2 of the Universal Declaration of Human Rights ${ }^{128}$; stating that all the provisions of the referred instrument have developed into customary laws without even analysing the material elements nor those pertaining to the spirit of the cus-

\footnotetext{
126 See App. 011/2011\& 001/2011, Tanganyika Law Society, Legal and Human Rights Centre, Rev. Christopher Mtikila v. United Republic of Tanzania, (14 June 2013), regarding the prohibition of independent applications in the presidential, parliamentary and local Tanzanian elections.

127 Considering that a majority of the cases which are known by the Court are about violations of the right to a fair trial, the decisions of the African Court on Human and Peoples' Rights have been mostly based on article 14 of the ICCPR, due to the fact it is more elaborated than article 7 of the African Charter. See App. Nr. 005/2013, Alex Thomas v. United Republic of Tanzania, Judgment, (20 November 2015), para. 89 and following; App. Nr. 001/2015, Armand Guebi v. United Republic of Tanzania, Judgment, (7 December 2018), paras. 73-79. Regarding this subject, on a doctrinal level, see appraisal". African Human Rights Law Journal, v. 1, n. 2, p. 268-284, 2001. MUJUZI, J. D. 'The African Court on Human and Peoples' Rights and Its Protection of the Right to a Fair Trial". The Law \& Practice of International Courts and Tribunals, v. 16, p. 187-223, 2017.

128 This provision establishes that "nobody should be arbitrarily deprived of their nationality nor of the right to change their nationality".
}

tom which is invoked and without specifying if we are before a universal or regional custom ${ }^{129}$.

In any case, in the face of the opinions which maintained the vast ratione materiae competence which was granted was going to cause divergent interpretations and a fragmentation in the application of the different human rights instruments, the Court has made remarkable use of a cross fertilization regarding the jurisprudential lines of thought of the protection and control bodies, thereby saving the critique with it ${ }^{130}$.

As for its ratione personae competences, article 5 of the Protocol assigns active direct legitimation before the Court to Member States, the Commission and African Intergovernmental Organizations.

Regarding the Commission, albeit its 2010 Regulation allowed for a quasi-judicial body to transfer a case to the Court at any stage of the analysis of the communication; in the case of non-compliance with the communication which is issued or of the provisional measures which are adopted; and in situations of grave and mass human rights violations ${ }^{131}$; in the 2020 Regulation it is only allowed to send the case in question to the Court before the Commission decided on its admissibility, which involves a very significant restriction to the functions of the Commission, and which undoubtedly is motivated by the abovementioned dispute between the quasi-judicial budget and the AU political bodies ${ }^{132}$.

Nevertheless, the Commission did not make use of the ample attributions given to it by the previous Regulation, as it only sent a case to the Court regarding three different issues; on the issues in African Commission on Human and Peoples' Rights (Benghazi) v. Libya -on the human rights violations committed by the Libyan security forces against the population while it was peacefully demonstrating against the Muamar el Gadafi regime within the period of the 2011 Arab Spring - African Commission (Saif al-Islam Gaddafi) v. Libya - on the detention, incarceration and sentencing to death of Saif al-Islam

\footnotetext{
${ }_{129}$ Regarding which the burden of proof, as we know, operates differently. See App. No. 012/2015, Anudo Ocbieng Anudo v. United Republic of Tanzania, Judgment, (22 March 2018), paras. 76 y ss.

${ }^{130}$ Using the previously mentioned case as an example, Anudo Ochieng Anudo v. United Republic of Tanzania, Cfr. references to General Observation Nr. 27 of the UN Human Rights Committee in para. 98.

131 See Rule 118 of the Commission 2010 Procedure Rules.

132 See Article 130.1 of the Commission 2020 Procedure Rules. See para. 3.1.1.
} 
Gaddafi, son of Muamar el Gadafi, without compliance with the guarantees of the right to a fair trial after the fall of the regime- and African Commission (Ogiek) v. Kenya-regarding the expropriation of the lands of the Ogiek indigenous people ${ }^{133}$. On the other hand, the Court can also send cases to the Commission, however, this function of the Court has barely been exercised and we do not know under which criteria ${ }^{134}$.

As for the legitimation of the Intergovernmental Organizations - another of the novelties in relation to the Interamerican and European Courts - the Court understood them as being "an association of States established by and based upon a treaty, which pursues common aims and which has its own special organs to fulfil particular functions within the organization"; not including the Committee of Experts on the Rights and Welfare of the Child in the referred concept due to the fact it is a body of the $\mathrm{AU}$, and hence this body cannot send cases to the Court ${ }^{135}$. In any case, we understand that the Regional Economic Communities could be included in this concept, even though, up until now, this provision has never been called upon ${ }^{136}$.

In addition to the three mentioned subjects which have direct access, unlike the Interamerican Court,

133 See App. Nr. 004/2011, African Commission on Human and Peoples' Rights v. Great Socialist People's Libyan Arab Jamabiriya; App. Nr. 002/2013, The African Commission on Human and Peoples' Rights v. Libya; y App. Nr. 006/2012, African Commission on Human and Peoples' Rights v. Republic of Kenya. The former, based on the grave human rights violations and the latter due to the lack of compliance with the adopted provisional measures. For a detailed analysis of these Libyan issues, see CARTES RODRÍGUEZ, J. B.; ÍÑIGO ÁLVAREZ, L., "The case law of the African Court on Human and Peoples' Rights in Libya following the Arab uprisings: Lessons learned for the consolidation and legitimation of the Court". African Human Rights Law Journal, v. 20, p. 78-102, 2020.

${ }^{134}$ No further than what is generally established in article 38.1 of the African Court on Human and Peoples' Rights Regulation. According to the information submitted to the Court website the issue was sent to the Commission only four times. See https://www. african-court.org/cpmt/statistic (Consultation date: 15.06.2021).

135 See Request Nr. 002/2013, The African Committee of Experts on the Rights and Welfare of the Child on the Standing of the African Committee of Experts on the Rights and Welfare of the Child Before the African Court on Human and Peoples' Rights, (5 December 2014), paras. 72 and following.

136 Albeit we should take into account that in the Gombert Jean-Claude Roger v. Republic of Côte d'Ivoire case the Court determined that it is ruled by the ne bis in idem rules regarding the cases which were already known by the Court of Justice of the Economic Community of West African States. See App. Nr. 038/2016, Gombert JeanClaude Roger v. Republic of Côte d'Ivoire, Judgment, (22 March 2018), para. 61. In such a way that the case should have been sent directly on the African Court on Human and Peoples' Rights. individuals and NGOs are also attributed active legitimation before the Court any time the respondent State - besides being Party to the Protocol - has made an additional statement of competence to such an effect ${ }^{137}$. Up to now, 10 States have proceeded in this way: Burkina Faso, Malawi, Mali, Ghana, Tunisia, Gambia, Ruanda, Tanzania, Ivory Coast and Benin. Si bien Ruanda retiró su declaración en 2016 y los tres últimos entre 2019 y $2020^{138}$. In any case, of the 98 procedural cases which are known of until today, almost all of them (except for the three cases which were submitted by the Commission) were presented by individuals and NGOs, which gives a good account of the importance of such an attribution and the challenge that its withdrawal represents for the future of the Court ${ }^{139}$.

Focusing on its content, the Court adopted a protectionist jurisprudence, thereby overcoming the shortcomings of the African Charter. Thus, for example, concerning claw back clauses, based on the jurisprudence of the Commission, the African Court on Human and People's Rights has sustained that such restrictions should be foreseen in a law; they should serve a legitimate purpose; and they should be necessary and proportional in a democratic society ${ }^{140}$. Even so, the Court carried out an adequate articulation of the rights of peoples in the already mentioned case of the African Commission (Ogiek) v. Kenya ${ }^{141}$, and in APDF \& IHRDA v. Republic of Mali it adopted a strong stance against child marriage and gender discrimination in inheritance

${ }^{137}$ See article 34.6 of the Protocol of the African Court on Human and Peoples' Rights. Among the bibliography published on this subject, see RIBEIRO DO NASCIMENTO, M. A. "O Acesso Do Indivíduo Às Instâncias De Proteção Do Sistema Africano De Proteção Dos Direitos Do Homem E Dos Povos". Revista de Direito Internacional, v. 9, n. 1, p. 103-124, 2012; CORBACHO NEVES DOS SANTOS, J. "Limites e Possibilidades Da Responsabilização Do Indivíduo No Direito Internacional e No Direito Interno". Revista de Direito Internacional, v. 8, n. 2, p. 19-69, 2011.

138 Information available at: https://www.african-court.org/ wpafc/declarations/ (Consulted on: 15.05.2021). For an analysis of the different reasons for the withdrawal, in their majority by decisions of the Court which raised a full disagreement by the respective Governments, see DE SILVA, N., "A Court in Crisis: African States' Increasing Resistance to Africa's Human Rights Court", Opinion Juris, 19 May 2020.

139 These cases may be consulted at: https://www.african-court. org/cpmt/finalised (Consulted on: 15.05.2021).

140 See App. Nr. 003/2014, Ingabire Victoire Umuboza v. Republic of Rwanda, Judgment, (24 November 2017), paras. 133 and 134 in fine; App. Nr. 004/2013, Lohe Issa Konate v. Burkina Faso, Judgment, (5 December 2014), para. 125.

${ }^{141}$ See App. Nr. 006/2012, African Commission on Human and Peoples' Rights v. Republic of Kenya, (26 May 2017). 
issues ${ }^{142}$; all of this by making use of a remarkable cross fertilization with the jurisprudence of bodies belonging with other systems, not only the regional ones but also the universal systems ${ }^{143}$.

In any case, a big part of the decisions have been on civil and political rights violations, particularly on the right to a fair trial; regarding which the Court interpreted article 7 of the African Charter on Human and Peoples' in line with the more elaborated article 14 of the ICCPR $^{144}$. Likewise, we must refer the more extensive protective interpretation carried out by the Court in the convictions to the death penalty based on article 4 of the Charter, requiring that it is imposed by a competent court; should be foreseen in a law; should comply with due process guarantees ${ }^{145}$.

As for reparations, the African Court on Human and Peoples' Rights adopted the advanced jurisprudential line of thought of the Interamerican Court and ordered reparation and compensation measures - not only for material damages or moral damages -satisfaction measures, measures of cessation or non-repetition measures ${ }^{146}$. Notwithstanding, one of the remaining challenges is the limited compliance with the adopted decisions ${ }^{147}$, which is intended to be corrected through

\footnotetext{
142 See App. No 046/2016, APDF \& IHRDA v. Republic of Mali, Judgement, (11 May 2018).

143 For example, regarding the referred subject, App. Nr. 006/2012, African Commission on Human and Peoples' Rights v. Republic of Kenya, (26 May 2017), See para. 106 -referring to the work of the UN Special Rapporteur on minority issues - and para. 181 -referring to the jurisprudence of the UN Committee on Economic, Social and Cultural Rights.

144 See App. Nr. 005/2013, Alex Thomas v. United Republic of Tanzania, Judgment, (20 November 2015), para. 89 and following; App. No. 006/2013, Wilfred Onyango Nganyi \& 9 Others v. United Republic of Tanzania, Judgment, (18 March 2016), para. 165 and ss.

145 See App. Nr. 007/2015, Ally Rajabu and Others v. United Republic of Tanzania, Judgment, (28th November 2019), para. 104.

146 As an example, we can find these measures in the issues in App. 011/2011, Rev. Christopher Mtikila vs. United Republic of Tanzania, Judgments on Reparations, (14 Jun 2013); App. 004/2013, Lohé Issa Konaté vs. Republic of Burkina Faso, Judgments on Reparations, (3 June 2016); App. 013/2015, Robert J. Penessis vs. United Republic of Tanzania, Judgments on Merits and Reparations App. 013/2017, Sébastien Germaine Marie Aikoué Ajavon v. Republic of Benin, Judgments on Reparations, (28 November 2019); App. 006/2015, Ngura Viking (Babu Seya) \& Another vs United Republic of Tanzania, Judgments on Reparations, (8 May 2020).

${ }^{147}$ Unlike the Commission, regarding the Court, broadly speaking, we can find updated information on the degree of compliance with the adopted decisions in its activity Reports, which are available at https://www.african-court.org/wpafc/ (Consultation date: 15.06.2021).
}

the adoption of a new regulation for situations of non-compliance, partially based on the existing rules in the European and Interamerican regional systems; an in the reinforcement of the role of the Court itself. Although the political bodies of the AU are also attributed a leading role, particularly the Committee of Permanent Representatives, the Executive Council and the Assembly of Heads of State and Government ${ }^{148}$.

\subsubsection{The African Court of Justice and Human Rights and the African Court of Justice and Human and Peoples' Rights.}

Currently, in the heart of the regional system, we are before a significant institutional reform process which is a particular responsibility of their judicial bodies.

Thus, as we pointed out, along with the African Court on Human and Peoples' Rights was created due to the 1998 Protocol, which entered into force in 2004; a year before, 2003, a Protocol was adopted that had the objective of establishing a Court of Justice for the African Union (CJAU), which entered into force in 2009 one it achieved fifteen ratifications ${ }^{149}$.

Nevertheless, this Court would never come into functioning, as was agreed in 2008 by the Heads of State and Government in the AU through the adoption of a new Protocol (which still has not entered into force) to merge the African Court of Human and Peoples' Rights and the African Court of Justice of the African

148 See Doc. EX.CL/1126 (XXXIV). In its turn, the African Court on Human and Peoples' Rights also has consultative jurisdiction, with active legitimation of AU Member States, the AU itself, its bodies or African organizations recognized by the AU. Nevertheless, up to now we only know of two consultative opinions: Advisory Opinion Nr. 002/2013, (5 December 2014) and Advisory Opinion Nr. 001/2018, (4 December 2020). The former states that the Committee of Experts on the Rights and Welfare of the Child, even though it has active legitimation on a consultative level, lacks active legitimation before the Court on a procedural level; and the latter, is on the different laws adopted by AU States persecuting vagrant people, and the fact they are incompatible with the provisions in the system treaties.

149 See Protocol of the Court of the African Union, which is available at https://au.int/en/treaties/ (Consulted on: 15.06.2021). For an analysis of this subject, see MAGLIVERAS, K. D.; NALDI, G. J. "The African Court of Justice". Zeitschrift für ausländisches öffentliches Recht und Völkerrecht, v. 66, p. 187-213, 2006; ELIAS, O. "Introductory Note to the Protocol on the Statute of the African Court of Justice and Human Rights". International Legal Materials, v. 48, p. 334-336, 2009. 
Union, leading to the African Court of Justice and $\mathrm{Hu}-$ man Rights (ACJHR) $)^{150}$.

In its turn, to make things more complicated, in 2014, in the context of the disagreement between the International Criminal Court and the African Union, mainly due to the immunity (or lack thereof) of Heads of State before the commission regarding international crimes, the Heads of State and Government of the African Union, before the 2008 Protocol came into force, decided to adopt a new Protocol which modified it, providing it (along with the Sections for General Issues and Human Rights) with a new International Criminal Law Section; resulting in the African Court of Justice on Human and Peoples' Rights (ACJHPR) ${ }^{151}$.

So currently we have four different Protocols, two of which are in force, but only one of them, the one from 1998, has a Court - the African Court on Human and Peoples' Rights -is in function; while the one from 2003 - the Court of Justice of the African Union - is not, nor is it expected to be due to the prior decision to merge.

Looking briefly into both the Protocols which are not yet in force, the one which establishes the African Court of Justice and Human Rights (2008) and the one which establishes the African Court of Justice and Human and Peoples' Rights (2014), we can see significant progression in both.

\footnotetext{
${ }^{150}$ See Protocol on the Statute of the African Court of Justice and Human Rights, which is available at https://au.int/en/treaties/ (Consultation date: 15.06.2021). Of the 15 necessary ratifications for its entry into force, currently only 8 are State Parties to the Protocol. For an analysis, see JUMA, D. "Lost (or Found) in Transition? The Anatomy of the New African Court of Justice and Human Rights". Max Planck Yearbook of United Nations Law, v. 13, n. 1, p. 267-306, 2009; OGWEZZY, M. C. "Challenges and Prospects of the African Court of Justice and Human Rights". Jimma University Journal of Law, v. 6, p. 1-30, 2014.

151 See Protocol which amends the Protocol on the Statute of the African Court of Justice and Human Rights (also called the Malabo Protocol), available at https://au.int/en/treaties/ (Consultation date: 15.06 .2021$)$. Of the 15 necessary ratifications for its entry into force, currently no States are a Party to the Protocol. For an analysis, see JALLOH, C. C.; CLARKE, K. M.; NMEHIELLE, V. O. (ed.). The African Court of Justice and Human and Peoples' Rights in Context: Development and Challenges. Cambridge: Cambridge University Press, 2019; NALDI, G. J.; MAGLIVERAS, K. D. “The International Criminal Section of the African Court of Justice and Human Rights: An Appraisal". African Yearbook of International Law, v. 21, n. 1, p. 293-341, 2016; CARTES RODRÍGUEZ, J. B., "The Proposed African Criminal Chamber: an Effective Tool to End Impunity on African Soil?”, Revista Electrónica Cordobesa de Derecho Internacional Público (Argentina), v. 1, p. 1-12, 2019.
}

Regarding the first, we point out the broadening of those who can legitimately present cases before the Human Rights Section. Thus, albeit for individuals and NGOs to be able to Access the Court an additional declaration of competence is still required from the respondent State, not only States, the Commission and the African Intergovernmental Organizations can present cases before the referred Section, but also the Parliament and any other AU body with the permission of the Assembly, National African Human Rights Institutions, and the Committee of Experts on the Rights and Welfare of the Child can present cases as well ${ }^{152}$. Thus, adding the Committee bridges the more significant omissions of the 1998 Protocol.

In its turn, regarding the 2014 Protocol, it points out, firstly, the existence of an application mechanism International Criminal Law within a regional human rights protection system, which is something completely unseen to date. Additionally, the ratione materiae and personae competences of the International Criminal Law Section is very extensive; the former include 14 international crimes $^{153}$, and the latter enable the African Court of Justice and Human Rights not only to be able to judge and convict individuals (as is the case of the ICC) but also legal entities ${ }^{154}$. Nevertheless, we are faced with important criticisms, the most significant of which perhaps being the granting of immunity not only to Heads of State, but also to any high standing public official during the period they are carrying out their functions ${ }^{155}$.

152 See articles 29-30 of the Annex to the Protocol of the African Court of Justice and Human Rights.

${ }^{153}$ See article 28A of the Annex of the Protocol of the African Court on Human and Peoples' Rights. In such a way that besides the war crimes, genocide, crimes against humanity and of aggression, on those which the ICC has competence over, the referred Protocol adds 10 more crimes, among them, terrorism, piracy, and human trafficking.

${ }^{154}$ See article 46C of the Annex to the Protocol of the African Court on Human and Peoples' Rights.

155 See article 46ABIS of the Annex to the Protocol of the African Court of Justice on Human and Peoples' Rights. For a more detailed analysis of the constitutive Protocol of the African Court of Justice on Human and Peoples' Rights, see JALLOH, C. C.; CLARKE, K. M.; NMEHIELLE, V. O. (ed.). The African Court of Justice and Human and Peoples' Rights in Context: Development and Challenges. Cambridge: Cambridge University Press, 2019; and specifically on the innexistence of jurisdiction immunity of Heads of State before the ICC, see CARTES RODRÍGUEZ, J. B. "Reflexiones en torno a la inmunidad de jurisdicción penal de los Jefes de Estados ante la comisión de crímenes internacionales en el marco del Estatuto de Roma". Anuario Español de Derecho Internacional, v. 35, p. 487-531, 2019. 


\subsubsection{Subregional courts with competencies in the area of human rights}

Shortly after 1963, when the Organization for African Unity was created, different Regional Economic Communities started to take shape on the continent, but without a direct bond with the International Organization. We had to wait until the 1980 Lagos Action Plan and the 1991 Abuja Treaty for the Economic Regional Communities to be considered a fundamental pillar in the economic development and integration of Africa, and providing in this way for their creation in the territories where they did not exist yet ${ }^{156}$. In this way, the Constitutive Act of the African Union already establishes among its objectives the "coordination and harmonization of policies among the different present and future - Regional Economic Communities for the progressive realization of the objectives of the Union" ${ }^{\prime 157}$. Furthermore, the Protocol on the Relations between the AU and the Regional Economic Communities states that the $\mathrm{AU}$ decisions will be binding to the latter, and that sanctions can even be imposed in case of non-compliance ${ }^{158}$.

There are currently over ten Regional Economic Communities, but only eight are recognized by the $\mathrm{AU}^{159}$. In their turn, of these eight communities not all of them have created courts within their internal structure, and not all the courts have issued decisions on issues directly related with human rights topics.

Only three have done so in a significant manner: the Southern African Development Community Tribunal, the East African Court of Justice and the Economic Community of West African States Court of Justice.

\footnotetext{
156 On the process of economic integration in Africa, see SAUROMBE, A. "An analysis of economic integration in Africa with specific reference to the African Union and the African Economic Community". Southern African Public Law, v. 27, n. 1, p. 292-314, 2012.

157 Article 3.1) of the AU Constitutive Act.

158 See article 22 of the Protocol on the Relations between the African Union and the Regional Economic Communities which was adopted in 2008.

159 These eight are: the Arab Maghreb Union; the Common Market for Eastern and Southern Africa; the Community of Sahel-Saharan States; the East African Community; the Economic Community of Central African States; the Economic Community of West African States; the Intergovernmental Authority for Development; and the Southern African Development Community. See https://au.int/en/ organs/recs Date of consultation: (15.05.2021).
}

Starting on the first, the Southern African Development Community (SADC) was created in 1992 and now has 16 Member States ${ }^{160}$. The SADC Court is added due to an additional Protocol from $2000^{161}$, nevertheless, only a few years after it started functioning, it had to resolve the controversial Campbe$\| l^{162}$ issue; regarding the expropriation of land by the Government of Zimbabwe regarding a minority of landowners of European descent, who owned the wealthiest parts of the country since colonial times. In 2008, the Court found that the State of Zimbabwe had incurred in racial discrimination, in violations to the right to a fair trial and had not provided the adequate reparations. Furthermore, the Court determined that there was no reasonable justification behind this measure, as the land in question had ended up in the hands of the next of kin of those of to the party in power. All based on articles 4.c and 6.2 of the SADC establishing Treaty, these provisions recognized the promotion and protection of human rights, democracy and the Rule of Law among the principles of the Community; and regarding which Zimbabwe upheld their non-justiciability ${ }^{163}$. From then on President Robert Mugabe not only would decide not to comply with the judgement, but also started an offensive against the Court which would result in the adoption of a restrictive Protocol in 2014 and in its de facto dismantling ${ }^{164}$.

Regarding the East African Community (EAC), it was created in 1999 and has 9 Member States ${ }^{165}$. Its es-

160 See Southern African Development Community Tribunal, of 17 August 1992; AU, "African Union Handbook", Jointly published by the African Union Commission and New Zealand Ministry of Foreign Affairs and Trade, Addis Ababa, Ethiopia, 2020, p. 161-162. 161 See Protocol on the Tribunal and the Regulation of the Southern African Development Community, of 7 August 2000. Its headquarters are in Gaborone (Botswana).

${ }_{162}$ See SADC Court, Campbell and Others v. Zimbabwe (Merits), Case Nr. SADC (T) 2/2007, 28 November 2008.

163 While in article 4.c it is established that "SADC and its Member States shall act in accordance with the following principles: (c) human rights, democracy and the rule of law"; in provision 6.2 reference is made specifically to the principle of non-discrimination, stating that "SADC and Member States shall not discriminate against any person on grounds of gender, religion, political views, race, ethnic origin, culture or disability".

164 Due to the referred Protocol, access of individuals to the Court is eliminated and State Parties are allowed to withdraw from its jurisdiction in the period of 12 months from the notification. See ALTER, K. J.; GATHII, J. T.; HELFER, L. R. "Backlash against international courts in west, east and southern Africa: causes and consequences". European Journal of International Law", v. 27, n. 2, p. 293-328, 2016.

165 See Treaty for the Establishment of the East African Com- 
tablishing treaty contemplates the creation of a Court of Justice which started functioning in $2001^{160}$, regarding which it is expressly established that for it to have competence on human rights subjects it is necessary to adopt an additional Protocol ${ }^{167}$. Notwithstanding, the EAC Court has been considered issues pertaining to human rights based on articles 6.d and 7.2 of the Treaty for the Establishment of the Community ${ }^{168}$, being one of the most significant issues the case of Anyang Nyong'o v. Attorney General of Kenya; where the Court determined that the State of Kenia had not carried out elections under the required democratic standards ${ }^{169}$. Due to this decision, its Government, like the Zimbabwean Government, started a campaign against the Court whi$\mathrm{ch}$, albeit would not end it but instead would result in the adoption of a Protocol which limited the deadlines for the presentation of legal claims and established an Appeals chambers made up of a majority of conservative judges ${ }^{170}$.

Lastly, the East African Economic Community of States, currently made up of 15 States was founded in 1975, and its establishing Treaty was revised in $1993^{171}$ to add among its principles "the recognition, the pro-

munity, of 30 November 1999; AU, "African Union Handbook", Jointly published by the African Union Commission and New Zealand Ministry of Foreign Affairs and Trade, Addis Ababa, Ethiopia, 2020, pp. 155-156.

166 See articles 23-47 of the Treaty for the Establishment of the East African Community. Its headquarters are in Arusha (Tanzania).

${ }^{167}$ See Article 27.2 of the Treaty for the Establishment of the East African Community.

${ }^{168}$ While the former established that "the fundamental principles that shall govern the achievement of the objectives of the Community by the Partner States shall include: (d) good governance including adherence to the principles of democracy, the rule of law, accountability, transparency, social justice, equal opportunities, gender equality, as well as the recognition, promotion and protection of human and people's rights in accordance with the provisions of the African Charter on Human and Peoples' Rights"; and in the latter it is stated that "the Partner States undertake to abide by the principles of good governance, including adherence to the principles of democracy, the rule of law, social justice and the maintenance of universally accepted standards of human rights".

169 See EAC Court, Anyang Nyong'o v. Attorney General of Kenya, Reference Nr. 1 of 2006, of 27 November 2006.

${ }^{170}$ See ALTER, K. J.; GATHII, J. T.; HELFER, L. R. "Backlash against international courts in west, east and southern Africa: causes and consequences". European Journal of International Law", v. 27, n. 2, p. 303-316, 2016.

${ }_{171}$ See the Treaty of the Economic Community of West African States, of 28 May 1975, revised in 1993; AU, "African Union Handbook", Jointly published by the African Union Commission and New Zealand Ministry of Foreign Affairs and Trade, Addis Ababa, Ethiopia, 2020, pp. 158-159. motion and the protection of human and peoples' rights according to the dispositions of the African Charter on Human and Peoples' Rights"172. In its turn, the Court of the Community was created in 1991 due to an additional Protocol which would be amended in 2005, incorporating ample competencies on human rights matters, as well the direct access of individuals regarding these issues ${ }^{173}$, and the lack of the need to exhaust internal means as a characteristic of its functioning ${ }^{174}$. In such a way that, of the three referred Courts, this is the only one which expressly has this competence. In the same way as in prior situations, due to the Manneh and Musa Saidykhan cases - both regarding journalists which had been incarcerated and submitted to torture due to the publication of certain articles against the Government of Gambia ${ }^{175}$ - there was an attempt to shut down the Court, which finally was successful ${ }^{176}$.

Since then, certain decisions in human rights matters have been being adopted, mostly using the African Charter on Human and Peoples' Rights as a referen$\mathrm{ce}^{177}$. Nevertheless, up until now, no document has been adopted to clarify the relationship between, on one hand, the African Court on Human and Peoples' Rights and, on the other, the East African Court of Justice and the Court of Justice of the Economic Community of West African States ${ }^{178}$. As was pointed out, it was not even specified if the Economic Regional Communities recognized by the AU have active legitimation before the African Court under the concept of "intergovernmental organizations". Thus, major clarity is necessary in this respect, as an adequate complementarity between

\footnotetext{
${ }^{172}$ See article 4. g) of the Revised Treaty of the Economic Community of West African States.

173 See articles 3.4; and 4.d of Protocol A/SP.1/01/05. Its network is in Abuja (Nigeria).

174 See ALTER, K. J.; HELFER, L. R.; MCALLISTER, J. R. “A new international human rights court for West Africa: The ECOWAS Community Court of Justice". American Journal of International Law, v. 107, n. 4, p. 755-756, 2013.

175 See ECOWAS Court, Manneh v. The Gambia, ECW/CCJ/ JUD/03/08, 5 June 2008; ECOWAS Court, Saidykhan v. The Gambia, ECW/CCJ/RUL/05/09, 30 June 2009.

${ }^{176}$ See ALTER, K. J.; GATHII, J. T.; HELFER, L. R. "Backlash against international courts in west, east and southern Africa: causes and consequences". European Journal of International Law”, v. 27, n. 2, p. 296-300, 2016.

177 See EBOBRAH, S. T. "Courts of Regional Economic Communities in Africa and Human Rights Law" In: KADELBACH, S., RENSMANN, T, RIETER E. (ed.). Judging International Human Rights. New York: Springer, 2019. p. 247-251.

178 No further than what was adopted by the Court in the subject referenced in footnote Nr. 136 infra.
} 
Regional Economic Communities and the African Court on Human and Peoples' Rights could lead to significant progress on the continent.

\section{Conclusions}

From what was exposed above in this paper, we can observe that, in comparison with the European and Interamerican systems, the African system was the last one to appear, and even though it still not well known or studied until today, it has seen a considerable development after 1981.

This date corresponds to the date of the adoption of the African Charter on Human and Peoples' Rights, the constitutive and cornerstone treaty of the system, which presents a series of specificities which are briefly pointed out - among which there is the early recognition of the interdependence and indivisibility of different human rights, which not only will inspire the drafting of the rest of the African treaties but also the later development of other systems.

And while the African Charter presents certain omissions or shortcomings, these will be overcome not only by their own protection and control mechanisms, as well as through legislative means; on this last aspect, pointing out that the adoption of the African Charter on the Rights and Welfare of the Child and the Protocol on the Rights of Women in Africa.

As for the protection and control mechanisms, the African Charter on Human and Peoples' Rights only contemplated the creation of one Commission, which has been adopting a more guarantee-based approach and an extensive interpretation of the different provisions of the Treaty, besides the limitations to its competencies and budgetary limitations, and the inaction (sometimes restriction) of the AU political bodies.

We see less advances regarding the Committee, which was created due to the African Charter on the Rights and Welfare of the Child, and that in its almost 20 years of existence only had six communications. Thus, two options open up: or strengthening the Committee with funds and staff, or making its existence and functions known throughout the continent; or, as a second option, transferring the functions of the Committee to the Commission, incrementing the Commission's fun- ds, and betting on a single but robust quasi-judicial mechanism in the system.

Similarly, besides the fact that the creation and set up of the African Court of Human and Peoples' Rights was slow to say the least, having the first taken place in 1998, as its first decision on the merits was not issued until 2013; currently it is obvious that the referred body contributed to the consolidation and strengthening of the system. It points out its vast ratione materiae competence and the possibility of individuals and NGOs to present cases directly before it if the respondent State, besides ratifying its Protocol, has presented an additional declaration of competence.

Nevertheless, the Court also finds itself before different challenges, and their solution will coin its path in the next years. Among the three most significant challenges, firstly, we have the clarity of the relationship with the Commission and the Economic Regional Communities, which can be better, as well as the relationship with their respective courts; secondly, the low compliance rate regarding its decisions, partially motivated by the recurring inaction of the AU political bodies in the implementation of their mandate; and, thirdly, due to the recent withdrawals of the referred additional declarations of competence on the part of a series of States.

Lastly, or fourthly, because it is also a challenge for the African Court on Human and Peoples' Rights, we are before a process of judicial reform which particularly affects the AU judicial bodies, and that, albeit, the proposed courts have incorporate celebrated progress, they also present us with considerable critiques; particularly, the recognition on the part of the African Court of Justice and Human and Peoples' Rights of immunity concerning criminal jurisdiction to Heads of State or high ranking public office positions.

Hence, the African Union, before creating new protection and control mechanisms, and for the sake of a greater and more effective promotion and defence of human rights on the continent, should consolidate and reinforce its existing mechanisms. The same line of thought should be applied regarding the different treaties which have already been created - and have little implementation until today - instead of creating and proposing new treaties. 


\section{References}

ADU-GYAMFI J.; KEATING F. "Convergence and Divergence Between the UN Convention on the Rights of Children, and the African Charter on the Rights and Welfare of the Child". Sacha Journal of Human Rights, v. 3, n. 1, p. 47-58, 2013.

AGBAKWA, S. C. "Reclaiming humanity: economic, social, and cultural rights as the cornerstone of African human rights". Yale Human Rights and Development Law Journal, v. 5, p. 177-216, 2002.

ALTER, K. J.; GATHII, J. T.; HELFER, L. R. "Backlash against international courts in west, east and southern Africa: causes and consequences". European Journal of International Law”, v. 27, n. 2, p. 293-328, 2016.

ALTER, K. J.; HELFER, L. R.; MCALLISTER, J. R. “A new international human rights court for West Africa: The ECOWAS Community Court of Justice". American Journal of International Law, v. 107, n. 4, p. 755-756, 2013.

ARBOLEDA, E. “The Cartagena Declaration of 1984 and its Similarities to the 1969 OAU Convention: A Comparative Perspective". International Journal of Refugee Law, v. 7, p. 87-101, 1995.

BADEJO, D. L. The African Union. New York: Chelsea Hause Publishers, 2008.

BERMEJO GARCÍA, R. "Los derechos humanos en Africa". Anuario Español de Derecho Internacional, v. 28, p. $18-37$.

BOJOSI, K. N.; WACHIRA, G. M. "Protecting indigenous peoples in Africa: An analysis of the approach of the African Commission on Human and Peoples' Rights". African Human Rights Law Journal, v. 6, n. 2, p. 382-406, 2006.

BURGORGUE-LARSEN L.; MONTOYA CESPEDES N., "El diálogo judicial entre la Corte Interamericana de Derechos Humanos y la Corte Europea de Derechos Humanos". In: BANDEIRA, G., URUEÑA, R., y TORRES PÉREZ, A. Protección multinivel de derechos bumanos. Barcelona: Red de Derechos Humanos y Educación Superior, 2013. p. 187-210.

CAMERA, S.; WEGNER, R. "Dreito humano à alimentação, (in)segurança alimentar e desenvolvimento: os desafios à realização progressiva na América Latina”. Revista de Direito Internacional, v. 14, n. 1, p. 21-34, 2017.
CARTES RODRÍGUEZ, J. B. “El Tribunal Africano de Derechos Humanos y de los Pueblos: ¿Hacia un África en Paz?”. Anuario Mexicano de Derecho Internacional, v. 17, p. 251-289, 2017.

CARTES RODRÍGUEZ, J. B. "La protección de la infancia en los conflictos armados en el Sistema Regional Africano de Protección de los Derechos Humanos". In: PÉREZ VILLALOBOS, M. C. (ed.). La protección de la infancia en los conflictos armados. Editorial Universidad de Granada (EUG), 2019. p. 225-238.

CARTES RODRÍGUEZ, J. B. "Reflexiones en torno a la inmunidad de jurisdicción penal de los Jefes de Estados ante la comisión de crímenes internacionales en el marco del Estatuto de Roma". Anuario Español de Derecho Internacional, v. 35, p. 487-531, 2019.

CARTES RODRÍGUEZ, J. B. "The Proposed African Criminal Chamber: an Effective Tool to End Impunity on African Soil?", Revista Electrónica Cordobesa de Derecho Internacional Público (Argentina), v. 1, p. 1-12, 2019.

CARTES RODRÍGUEZ, J. B.; ÍÑIGO ÁLVAREZ, $L$. "The case law of the African Court on Human and Peoples' Rights in Libya following the Arab uprisings: Lessons learned for the consolidation and legitimation of the Court". African Human Rights Law Journal, v. 20, p. 78-102, 2020.

CHIRWA D. M. "Reclaiming (Wo)manity: the Merits and Demerits of the African Protocol on Women's Rights". Netherlands International Law Review, v. 53, n. 1, p. 63-96, 2006.

CHIRWA, D. M. "The merits and demerits of the African Charter on the Rights and Welfare of the Child". The International Journal of Children's Rights, v. 10, n. 2, p. 157-177, 2002.

CHIRWA, D. M. "Toward Revitalizing Economic, Social, and Cultural Rights in Africa". Human Rights Brief, v. 10, n. 1, p. 14-25, 2002.

COOMANS, F. "The Ogoni Case Before the African Commission on Human and Peoples' Rights". The International and Comparative Law Quarterly, v. 52, n. 3, p. 749-760, 2003.

CORBACHO NEVES DOS SANTOS, J. "Limites e Possibilidades Da Responsabilização Do Indivíduo No Direito Internacional e No Direito Interno". Revista de Direito Internacional, v. 8, n. 2, p. 19-69, 2011. 
DUGARD, C. J. "The Organisation of African Unity and Colonialism: an Inquiry into the Plea of Self-Defence as a Justification for the use of Force in the Eradication of Colonialism". International and Comparative Law Quarterly, v. 16, n. 1, p. 157-190, 1967.

EBOBRAH, S. T. "Courts of Regional Economic Communities in Africa and Human Rights Law". In: KADELBACH, S., RENSMANN, T, RIETER E. (ed.). Judging International Human Rights. New York: Springer, 2019. p. 223-254.

ELIAS, O. "Introductory Note to the Protocol on the Statute of the African Court of Justice and Human Rights”. International Legal Materials, v. 48, p. 334-336, 2009.

ELIAS, T. O. "The Charter of the Organization of African Unity". The American Journal of International Law, v. 59, n. 2, p. 243-267, 1965.

EVANS, M.; MURRAY, R. "The State Reporting Mechanism of the African Charter". In: EVANS, M., y MURRAY, R. (ed.). The African Charter on Human and Peoples' Rights: The System in Practice, 1986-2006. Cambridge: Cambridge University Press, 2008. p. 49-75.

FONTANIVE LEAL, A. A.; MASSAÚ, G., "Justiciabilidade Direta Dos Direitos Econômicos, Sociais, Culturais E Ambientais $\mathrm{Na}$ Corte Interamericana De Direitos Humanos". Revista de Direito Internacional, v. 18, n. 1, p. 334-351, 2021.

FRISSO, G. M. "Crianças-Soldado No Conflito Em Serra Leoa: Direitos Humanos, Direito Internacional Humanitário E/Ou Direito International Penal". Revista de Direito Internacional, v. 9, n. 2, p. 83-91, 2012.

GITTLEMAN, R. "The African Charter on Human and Peoples' Rights: A Legal Analysis". Virginia Journal of International Law, v. 22, p. 667-714, 1981.

GLEN, P. J. "Institutionalizing democracy in Africa: a comment on the African Charter on Democracy, Elections and Governance". African Journal of Legal Studies, v. 5, n. 2, p. 119-146, 2012.

HANFFOU NANA, S. La Cour africaine des droits de l'homme et des peuples: étude à la lumière de l'expérience européenne. Saint Denis: Editions Publibook, 2016.

HEYNS, C. "La Carta Africana de Derechos humanos y de los Pueblos" In: GÓMEZ ISA, F. (ed.). La protección internacional de los derechos humanos en los albores del siglo XXI. Bilbao: Universidad de Deusto, 2003. p. 595-620.
HEYNS, C. "The African Regional Human Rights System: In Need of Reform?". African Human Rights Law Journal, v. 1 n. 2, p. 155-174, 2001.

HEYNS, C. "The African Regional Human Rights System: The African Charter". Penn State Law Review, v. 108, n. 3, p. 679-702, 2004.

HEYNS, C. Human Rights Law in Africa. Leiden: Martinus Nijhoff Pubishers, 2004.

ÍNIGO ÁLVAREZ, L. Towards a regime of responsibility of armed groups in international law. Cambridge: Intersentia, 2019.

INTERNATIONAL COMMISSION OF JURISTS. Report on the proceedings of the African Conference on the Rule of Law. Lagos (Nigeria), January 3-7, 1961.

JALLOH, C. C.; CLARKE, K. M.; NMEHIELLE, V. O. (ed.). The African Court of Justice and Human and Peoples' Rights in Context: Development and Challenges. Cambridge: Cambridge University Press, 2019.

JUMA, D. "Lost (or Found) in Transition? The Anatomy of the New African Court of Justice and Human Rights". Max Planck Yearbook of United Nations Law, v. 13, n. 1, p. 267-306, 2009.

KIDANE, W. "Managing Forced Displacement by Law in Africa: The Role of the New African Union IDPs Convention". Vanderbilt Journal of Transnational Law, v. 44, n. 1, p. 1-85, 2011.

KIWANUKA, R. N. "The meaning of "people" in the African Charter on Human and Peoples' Rights". American Journal of International Law, v. 82, n. 1, p. 80-101, 1988.

KOIS, L. "Article 18 of the African Charter on Human and Peoples' Rights: A Progressive Approach to Women's Human Rights". East African Journal of Peace and Human Rights, v. 3, p. 92-114, 1997.

LANGELY, W. E.; OKOLO, J. E.; LANGLEY, W. E. "The Organization of African Unity and Apartheid: constraints on resolution". World Affairs, v. 137, n. 3, p. 206-232, 1974.

LLOYD A. "Evolution of the African Charter on the Rights and Welfare of the Child and the African Committee of Experts: Raising the gauntlet". The International Journal of Children's Rights, v. 10, n. 1, p. 179-198, 2002. 
LÓPEZ MARTÍN, A. G. "La doctrina del consejo de estado sobre los efectos jurídicos de los dictámenes de los comités de derechos humanos de Naciones Unidas". In: FERNÁNDEZ DE CASADEVANTE ROMANÍ, C. (coord.). Los efectos jurídicos en España de las decisiones de los órganos internacionales de control en materia de derechos bumanos de naturaleza no jurisdiccional. Madrid: Dykison, 2020.

LYNCH, G. "Becoming indigenous in the pursuit of justice: The African Commission on Human and Peoples' Rights and the Endorois" African Affairs, v. 111, n. 442, p. 24-45, 2012.

MAGLIVERAS, K. D.; NALDI, G. J. "The African Court of Justice". Zeitschrift für ausländisches öffentliches Recht und Völkerrecht, v. 66, p. 187-213, 2006.

MALUWA, T. "The constitutive act of the African Union and institution-building in postcolonial Africa". Leiden Journal of International Law, v. 16, n. 1, p. 157-170, 2003.

MANJOO, R. "Rights of the Vulnerable under the African System Women's Human Rights in Africa". In: SSENYONJO M. (ed.). The African Regional Human Rights System: 30 Years after the African Charter of Human and Peoples' Rights. Leiden/Boston: Martinus Nijhoff Publishers, 2012. p. 135-154.

MBONDENYI, K. "The African Charter on Human and Peoples' Rights". In: MBONDENYI, K. (ed.). International Human Rights and their Enforcement in Africa. Oxford/Nairobi: Law Africa Publishing, 2011.

MUGWANYA, G. W. "Examination of state reports by the African Commission: A critical appraisal". African Human Rights Law Journal, v. 1, n. 2, p. 268-284, 2001.

MUJUZI, J. D. “The African Court on Human and Peoples' Rights and Its Protection of the Right to a Fair Trial". The Law \& Practice of International Courts and Tribunals, v. 16, p. 187-223, 2017.

MULUGETA ABEBE, A. "The African Union Convention on internally displaced persons: Its codification background, scope, and enforcement challenges". Refugee Survey Quarterly, v. 29, n. 3, p. 28-57, 2010.

MURRAY, R. 'Women's Rights and the Organization of African Unity and African Union: The Protocol on the Rights of Women in Africa", in BUSS, D. y MANJI, A. (ed.). International Law: Modern Feminist Approaches. Oxford: Hart Publishing, 2005. p. 253-272.
MURRAY, R. Human rights in Africa: from the OAU to the African Union. Cambridge: Cambridge University Press, 2004.

MURRAY, R. The African Charter on Human and Peoples' Rights: A Commentary. Oxford: Oxford University Press, 2019.

MURRAY, R. The African Commission on Human and Peoples' Rights and International Law. Oxford: Hart Publishing, 2000.

NALDI, G. J. "Limitation of Rights Under the African Charter on Human and Peoples' Rights: The Contribution of the African Commission on Human and Peoples' Rights". South African Journal on Human Rights, v. 17, n. 1, p. 109-118, 2001.

NALDI, G. J.; MAGLIVERAS, K. D. “The International Criminal Section of the African Court of Justice and Human Rights: An Appraisal". African Yearbook of International Law, v. 21, n. 1, p. 293-341, 2016.

NETO DIAS FRANCO, L.; FERNANDEZ DE BASTOS, D. "O processo e o direito coletivo no sistema interamericano de direitos humanos: uma análise com base na jurisprudência internacional". Revista de Direito Internacional, v. 10, n. 2, p. 250-261, 2013.

NMEHIELLE, V. O. "The African Union and African Renaissance: A New Era for Human Rights Protection in Africa?". Singapore Journal of International \& Comparative Law, v. 7, p. 412-446, 2003.

NSIBIRWA, M. S. "A brief analysis of the Draft Protocol to the African Charter on Human and Peoples' Rights on the Rights of Women". African Human Rights Law Journal, v. 1, n. 1, p. 40-63, 2001.

OGWEZZY, M. C. "Challenges and Prospects of the African Court of Justice and Human Rights". Jimma University Journal of Law, v. 6, p. 1-30, 2014.

OKOTH-OBBO, G. Thirty years on: A legal review of the 1969 OAU Refugee Convention Governing the Specific Aspects of Refugee Problems in Africa. Refugee Survey Quarterly, v. 20, n. 1, p. 79-138, 2001.

PACKER, C. A.; RUKARE, D. "The new African Union and its constitutive act". American Journal of International Law, p. 365-379, 2002.

PADELFORD, N. J. "The Organization of African Unity”. International Organization, v. 18, n. 3, p. 521-542, 1964. 
QUASHIGAH, K. "The African Charter on Human and Peoples' Rights: Towards a more effective reporting mechanism". African Human Rights Law Journal, v. 2, n. 2, p. 261-300, 2002.

REBOUCHE, R. 'Labor, Land and Women's Rights in Africa: Challenges for the New Protocol on the Rights of Women". Harvard Human Rights Journal, v. 19, n. 1, p. 235-256, 2006.

RESENDE, A. "A Proteção do Meio Ambiente no Sistema Interamericano de Direitos Humanos a partir do direito à Educação". Revista de Direito Internacional, v. 10, n. 2, p. 297-314, 2013.

RIBEIRO DO NASCIMENTO, M. A. “O Acesso Do Indivíduo Às Instâncias De Proteção Do Sistema Africano De Proteção Dos Direitos Do Homem E Dos Povos". Revista de Direito Internacional, v. 9, n. 1, p. 103-124, 2012.

SAAVEDRA ÁlVAREZ, Y. "El Sistema Africano de Derechos Humanos y de los Pueblos". Anuario Mexicano de Derecho Internacional, v. 8, p. 671-712, 2008.

SAMPAIO LEITE, J. A.; SOUZA COSTA, B. "As complicadas inter-relações entre os sistemas internos e internacionais de proteção do direito ao meio ambiente sadio", Revista de Direito Internacional, v. 12, n. 2, p. 785 803, 2015.

SAUROMBE, A. "An analysis of economic integration in Africa with specific reference to the African Union and the African Economic Community". Southern African Public Law, v. 27, n. 1, p. 292-314, 2012.

SHARPE, M. "The 1969 African Refugee Convention: Innovations, Misconceptions, and Omissions". McGill Law Journal, v. 58, n. 1, p. 95-147, 2012.

UMOZURIKE, U. O. “The African Charter on Human and Peoples' Rights", The American Journal of International Law, v. 77, n. 4, p. 902-912, 1983.

VIEGAS REICHARDT, F; EDUARDO GARAVELLO, M. E. "Quando Habitar Corresponde Ao Direito Humano À Alimentação". Revista de Direito Internacional, v. 14, n. 1, p. 68-79, 2017.

VILJOEN F. et. al. A Guide To The African Human Rights System: Celebrating 30 Years Since the Inauguration of the African Commission on Human and Peoples' Rights. Pretoria, Center for Human Rights University of Pretoria, University Law Press, 2017.
VILJOEN, F. "An Introduction to the Protocol to the African Charter on Human and Peoples' Rights on the Rights of Women in Africa". Washington and Lee Journal of Civil Rights and Social Justice, v. 16, n. 1, p. 11-45, 2009.

VILJOEN, F. International Human Rights Law in Africa. Oxford: Oxford University Press, 2012.

VILJOEN, F.; LOUW, L. "State Compliance with the Recommendations of the African Commission on $\mathrm{Hu}-$ man and Peoples' Rights, 1994- 2004". American Journal of International Law, v. 101, n. 1, p. 1-34, 2007.

WALRAVEN, V. K. Dreams of power: The role of the Organization of African Unity in the politics of Africa: 1963-1993. London: Routledge, 1999.

WELCH, C. E. "The Organisation of African Unity and the promotion of human rights". The Journal of Modern African Studies, v. 29, n. 4, p. 535-555, 1991. 
Para publicar na Revista de Direito Internacional, acesse o endereço eletrônico www.rdi.uniceub.br ou www.brazilianjournal.org.

Observe as normas de publicação, para facilitar e agilizar o trabalho de edição. 